Article

\title{
Heme, A Metabolic Sensor, Directly Regulates the Activity of the KDM4 Histone Demethylase Family and Their Interactions with Partner Proteins
}

\author{
Purna Chaitanya Konduri ${ }^{+}\left[\right.$, Tianyuan Wang ${ }^{\dagger}$, Narges Salamat and Li Zhang * ${ }^{\mathbb{C}}$ \\ Department of Biological Sciences, University of Texas at Dallas, Mail Stop RL11, 800 W. Campbell Road, \\ Richardson, TX 75080, USA; pxk121430@utdallas.edu (P.C.K.); txw130830@utdallas.edu (T.W.); \\ nxs158730@utdallas.edu (N.S.) \\ * Correspondence: li.zhang@utdallas.edu; Tel.: +1-972-883-5757 \\ + These authors contributed equally to this paper.
}

Received: 7 February 2020; Accepted: 19 March 2020; Published: 22 March 2020

\begin{abstract}
The KDM4 histone demethylase subfamily is constituted of yeast JmjC domain-containing proteins, such as Gis1, and human Gis1 orthologues, such as KDM4A/B/C. KDM4 proteins have important functions in regulating chromatin structure and gene expression in response to metabolic and nutritional stimuli. Heme acts as a versatile signaling molecule to regulate important cellular functions in diverse organisms ranging from bacteria to humans. Here, using purified KDM4 proteins containing the JmjN/C domain, we showed that heme stimulates the histone demethylase activity of the JmjN/C domains of KDM4A and Cas well as full-length Gis1. Furthermore, we found that the C-terminal regions of KDM4 proteins, like that of Gis1, can confer heme regulation when fused to an unrelated transcriptional activator. Interestingly, biochemical pull-down of Gis1-interacting proteins followed by mass spectrometry identified 147 unique proteins associated with Gis1 under heme-sufficient and/or heme-deficient conditions. These 147 proteins included a significant number of heterocyclic compound-binding proteins, Ubl-conjugated proteins, metabolic enzymes/proteins, and acetylated proteins. These results suggested that KDM4s interact with diverse cellular proteins to form a complex network to sense metabolic and nutritional conditions like heme levels and respond by altering their interactions with other proteins and functional activities, such as histone demethylation.
\end{abstract}

Keywords: Gis1; KDM4; heme; histone demethylase; protein interaction; JmjC domain

\section{Introduction}

Histone lysyl demethylases (KDMs) play important roles in chromatin remodeling and gene regulation by catalyzing the demethylation of methylated lysine residues on the N-terminal tails of histones [1]. The majority of KDMs are JmjC domain-containing proteins, which are dioxygenases that use $\alpha$-ketoglutarate and $\mathrm{Fe}^{2+}$ to oxidize various substrates [2-4]. The KDM4 family, containing five members, i.e., KDM4A-E, accepts mono-, di- and trimethylated lysines as substrates [5,6]. KDM4A/B/C (Figure 1), but not KDM4D or E, contain the JmjC domain in the $\mathrm{N}$-terminus as well as Tudor and plant homeodomain (PHD) domains in the C-terminus. KDM4A/B/C are widely expressed, and their orthologues are found among all vertebrates $[7,8]$. KDM4A/B/C share more than $50 \%$ sequence identity (Figure 1) and catalyze the demethylation of tri- and di-methylated forms of both histone H3 lysine 9 (H3K9me3/me2) and lysine 36 (H3K36me3/me2) [3,9-13]. KDM4 proteins play important roles in diverse biological processes, including oncogenesis, inflammation, and hematopoiesis [8,14-16]. It is worth noting that the histone demethylase activity of KDM4s requires $\alpha$-ketoglutarate, $\mathrm{O}_{2}$, and $\mathrm{Fe}^{2+}$, which are important nutritional and metabolic indicators. Thus, histone demethylase activity is linked to and is highly responsive to nutrient status [17-22]. 


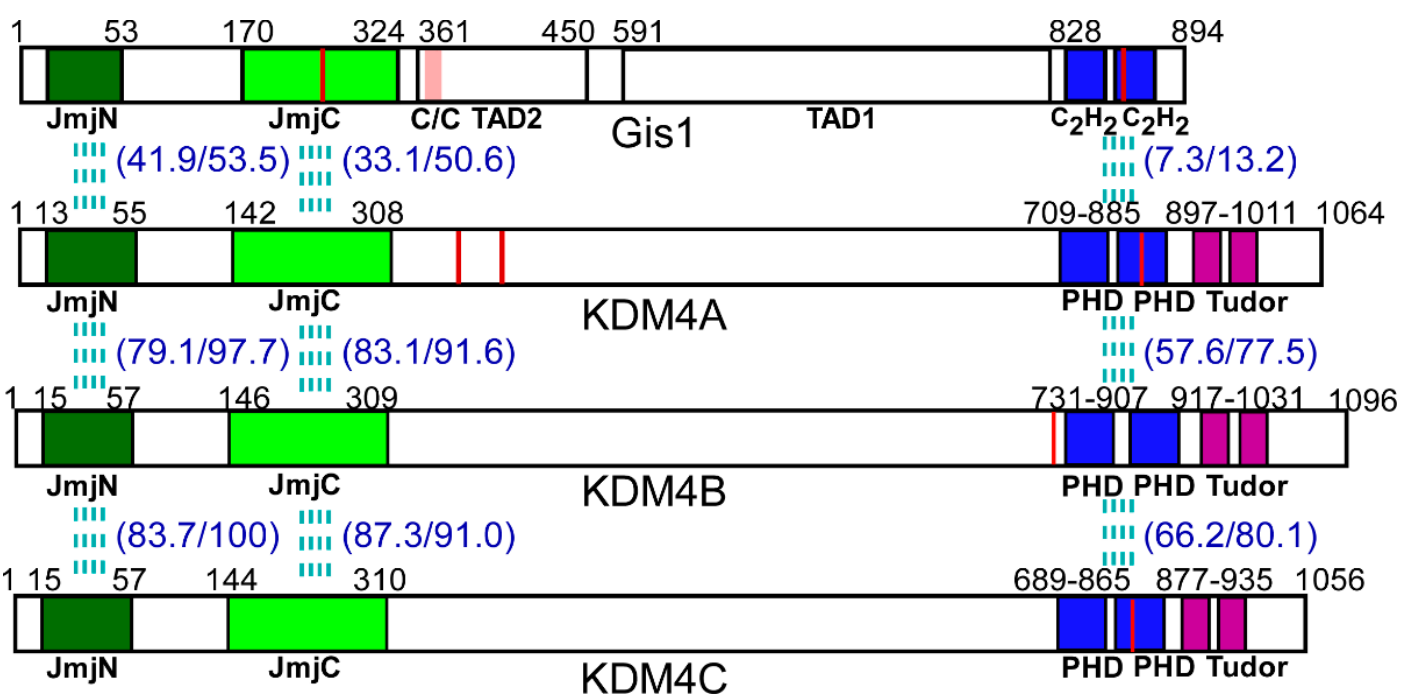

Figure 1. The structure and alignment of Gis1 and KDM4A/B/C domains. The domains of Gis1 and KDM4s are shown. Gis1 contains the JmjN + JmjC (JmjN/C) domain, the coiled-coil domain (C/C), two $\mathrm{C} 2 \mathrm{H} 2$ type zinc fingers ( $\mathrm{ZnFs}$ ), and two transcription activation domains (TAD1 and TAD2). $\mathrm{KDM} 4 \mathrm{~A} / \mathrm{B} / \mathrm{C}$ proteins contain the JmjN/C domain, two PHD domains (each containing a conserved $\mathrm{C} 4 \mathrm{HC} 3$ or $\mathrm{C} 4 \mathrm{HC} 2 \mathrm{H}$ motif), and two Tudor domains. The red lines represent cysteine-proline (CP) motifs, black lines indicate the start and end of the shown domains, and the pink box in the Gis1 structure denotes the coiled-coil domain. The \% amino acid identity and similarity between Gis1 and KDM4s in JmjN/C and zinc finger domains are shown in parentheses.

The yeast JmjC domain-containing protein Gis1 is an orthologue of KDM4 proteins. Previous data, including our own recent data, showed that Gis1 possesses histone demethylase activity at H3K36 [23-26]. In yeast, Gis1 is one of the key regulators mediating transcriptional reprogramming of carbon metabolism and stress responses during diauxic and post-diauxic shifts [27-32]. Gis1 binds to the post-diauxic shift (PDS) DNA element and can both activate and repress transcription [33-35]. It acts downstream of TOR, RAS/CAMP, and AKT/Sch9 signaling pathways in response to nutrient status [28,30,32]. Gis1 contains multiple domains, including a JmjN region, a JmjC region, a coiled-coil domain, two $\mathrm{C} 2 \mathrm{H} 2$ type zinc fingers $(\mathrm{ZnFs})$, and two transcription activation domains (TADs) (Figure 1) [30,36,37]. JmjN and JmjC interact physically to form a structural unit or a domain [37]. The $\mathrm{JmjN} / \mathrm{C}$ domain presumably confers histone demethylase activity, but is dispensable for transcriptional activation by Gis1 [36]. This Gis1 JmjN/C domain is highly homologous to those of $\mathrm{KDM} 4 \mathrm{~A} / \mathrm{B} / \mathrm{C}$, while the $\mathrm{C}$-terminal regions of Gis1 and KDM4A/B/C share low homology (Figure 1). The Gis1 zinc fingers allow Gis1 to bind to DNA and regulate transcription [30,36,37]. The C-terminal regions of KDM4A/B/C proteins contain two PHDs and two Tudor domains (Figure 1). The PHD domain is a protein module containing $\sim 50$ amino acid residues with a conserved $\mathrm{C} 4 \mathrm{HC} 3$ or $\mathrm{C} 4 \mathrm{HC} 2 \mathrm{H}$ motif that coordinates two zinc ions in a cross-brace configuration [38]. The Tudor domain typically contains $\sim 60$ amino acids that comprise 4-5 antiparallel $\beta$-strands to form a barrel-like structure [39]. Both PHD and Tudor domains are histone reader domains that recognize post-translationally modified histones, such as methylated H3 [40-43]. Although the JmjN/C domains of Gis1 and KDM4s are highly conserved, the C-terminal domain sequences of Gis1 are quite different, and there is no homology between the TADs of Gis1 and the corresponding regions of KDM4s (Figure 1). Thus, we do not expect that KDM4s can substitute for Gis1 in yeast.

Interestingly, our recent studies showed that heme promotes both transcriptional and histone demethylase activities of Gis1 [23]. Heme can bind to both the JmjN/C and $\mathrm{ZnF}$ domains, however, heme binding to the JmjN/C domain is not necessary for heme regulation of Gis1 activity. In contrast, heme binding to the $\mathrm{ZnF}$ domain promotes heme activation of both transcriptional and histone demethylase activities [23]. Under heme-deficient conditions, Gis1 is free of heme and is inactive. Its 
activities are repressed by the $\mathrm{ZnF}$ domain, which likely cooperates with other cellular proteins. When heme levels increase, heme binds to the $\mathrm{JmjN} / \mathrm{C}$ and $\mathrm{ZnF}$ domains, presumably causing other cellular proteins to dissociate from Gis1 and alter Gis1 conformation, thereby leading to full activation of Gis1 transcriptional and demethylase activities. Heme acts as a prosthetic group or cofactor in proteins and enzymes required for oxygen utilization and metabolism, such as globins and cytochromes [44-47]. Heme serves as a signaling molecule regulating diverse processes ranging from gene transcription to circadian rhythm [48-50]. Heme directly binds to and modulates the activities of certain cellular proteins, such as the yeast heme-regulatory protein Hap1 [51,52] and the mammalian nuclear receptor Rev-erb $\alpha[49,53]$. Experimental studies have increasingly shown that heme is a central signaling molecule in an array of physiological and pathological processes, including neurodegeneration, tumorigenesis, and adipogenesis [54-56].

Because Gis1 can sense heme and change its transcriptional and histone demethylase activities in response to heme, we asked if heme also regulates the activity of the human KDM4 family members, particularly, KDM4A/B/C which, like Gis1, not only contain the conserved JmjN/C domain, but also the C-terminal region with PHD zinc fingers (Figure 1). Interestingly, our data showed that heme strongly activates histone demethylase activity of KDM4A and C, but not KDM4B, while heme binds to all three. Furthermore, we identified other cellular proteins that are critical for heme regulation of Gis1. We found that 147 proteins could bind to Gis1 in vitro, notably, the transcriptional regulator Mot3 [57,58], which binds to Gis1 and is required for heme activation of Gis1 activity. Our data showed that heme is a conserved regulatory factor for KDM4 proteins and that heme regulation of Gis1 and likely other KDM4s involves a network of cellular proteins.

\section{Materials and Methods}

\subsection{Yeast Strains and Plasmids}

The yeast strains used were BY4741 (MATa his3 $\Delta 1$ leu2 $\Delta 0$ met15 $\Delta 0$ ura3 $\Delta 0$ ), MHY101 (MATa ura3-52 leu2-3,112 his4-519 ade1-100 hem1- 100 URA3::PDS-lacZ), MHY101 gis1 (MATa ura3-52 leu2-3,112

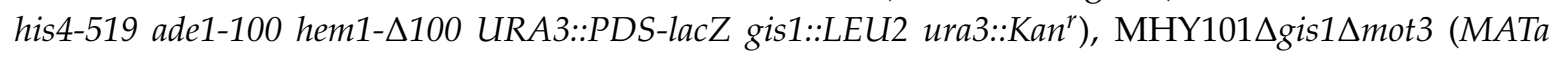
ura3-52 leu2-3,112 his4-519 ade1-100 hem1-D100 URA3::PDS-lacZ gis1::LEU2 mot3::HIS4 ura3::Kan ${ }^{r}$ ), and BWG1-7b_gis1 (MATa ura3-52leu2-3,112 his4-159 ade1-100 URA3::PDS-lacZ gis1::LEU2 ura3::Kan ${ }^{r}$ ). The Yeast Tandem Affinity Purification (TAP) Fusion Library (scTAP) comprised of 4247 Open Reading Frames (ORFs), was purchased from Open Biosystems (Cat. No. YSC1177).

To delete the GIS1 gene, MHY101 cells were transformed with a PCR product containing the LEU2 gene in the middle and 44 bps sequences flanking the open reading frame sequence of GIS1 on both sides. Knockout strains were confirmed by PCR and $\beta$-galactosidase assay. To delete the MOT3 gene, MHY101 $\triangle$ gis1 cells were transformed with a PCR product containing the HIS4 gene in the middle and 44 bps sequences flanking the open reading frame sequence of MOT3 on both sides. Knockout strains were confirmed by PCR. The PDS element-driven LEU2-lacZ reporter was introduced by transforming yeast strains with the with linearized, NcoI-cut pLS9-PDS plasmid, as described previously [34]. In the MHY101 $\triangle$ gis1 strain, the URA3 gene was deleted by transformation with a PCR product containing $\mathrm{Kan}^{\mathrm{r}}$ sequence in the middle and $44 \mathrm{bps}$ of sequence flanking the open reading frame sequence of URA3 on both sides.

The PDS element-driven LEU2-lacZ reporter plasmid pLS9-PDS was as described [34], and was provided by Dr. Claudio de Virgilio's lab (University of Fribourg, Fribourg, Switzerland).

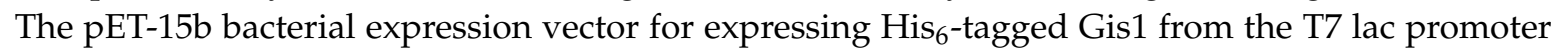
was as described [59], and was provided by Dr. George M. Carman's lab (Rutgers University, New Brunswick, NJ, USA). The pET-15b bacterial expression vector for expression of the $\mathrm{His}_{6}$-tagged $\mathrm{JmjN} / \mathrm{C}$ domain of Gis1 from the T7 lac promoter was as described [23]. The JmjN/C domains of $\mathrm{KDM} 4 \mathrm{~A} / \mathrm{B} / \mathrm{C}$ were cloned into the T7 expression vector $\mathrm{pET}-15 \mathrm{~b}$ cut with NdeI/BamHI, NdeI/XhoI, or Xhol/BamHI respectively. The coding sequences were confirmed by DNA sequencing (Eurofins MWG 
operon, Louisville, KY, USA). The yeast expression vectors for full-length Gis1 (pYY53), Gis1 $\triangle$ JmjC (pYY54), and Gis1 $\triangle \mathrm{ZnF}$ (pYY55) were as described [36], and were provided by Dr. Rolf Sternglanz's lab (Stony Brook University, Stony Brook, NY, USA). The expression vector for Gis $1 \Delta \mathrm{JmjN} / \mathrm{C}$ was as described [37,60], and was provided by Dr. Nianshu Zhang's lab (University of Cambridge, UK). The expression vectors for the fusion proteins Hap1-Gis $\Delta$ ZnF, Hap1-Gis1, Hap1-KDM4A, Hap1-KDM4B, and Hap1-KDM4C were constructed by inserting the coding sequences for the fusion proteins to the yeast expression vector SD5-HAP1 [61]. The DNA containing the coding sequences for fusion proteins was generated by overlapping PCR, as described previously [62]. The sequences of fusion proteins were confirmed by DNA sequencing using Eurofins MWG operon USA.

\subsection{Cell Growth and $\beta$-Galactosidase Assays}

Yeast cells were grown in rich yeast extract peptone dextrose (YPD) or synthetic complete media, as described previously $[63,64]$. Cell density was determined by measuring optical density at $600 \mathrm{~nm}$. To determine $\beta$-galactosidase levels from reporter genes in $\Delta$ hem 1 cells bearing the PDS element-driven LEU2-lacZ reporter or the Hap1-driven UAS1-CYC1-lacZ reporter, cells were grown in synthetic complete medium containing a limiting amount of the heme precursor 5-aminolevulinic acid (ALA, $2.5 \mu \mathrm{g} / \mathrm{mL})$ or a high amount of ALA $(250 \mu \mathrm{g} / \mathrm{mL})$. Cells were collected after they reached an optical density $(600 \mathrm{~nm})$ of approximately 1.0-1.5 to measure Gis1 and Hap1 activities. Collected cells were then subjected to chloroform permeabilization and $\beta$-galactosidase assays. The activities were measured and calculated in Miller units, as described previously [65,66].

\subsection{Purification of KDM4 and Gis1 proteins, Spectroscopic Analyses, and Protein Binding to Heme-Agarose Beads}

To purify the JmjN/C domains of KDM4A/B/C or full-length JmjN/C of Gis1 from Escherichia coli, BL21(DE3) bearing the pET-15b expression plasmids were grown to $A_{0.5}$, then induced with $1 \mathrm{mM}$ isopropyl $\beta$-D-1-thiogalactopyranoside (IPTG) for $2 \mathrm{~h}$ at $25^{\circ} \mathrm{C}$. Cells were collected and lysed with

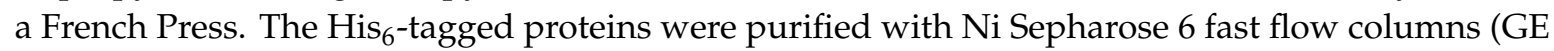
Healthcare, Chicago, IL, USA), according to the manufacturer's protocol. The eluted His 6 -Gis1 or $\mathrm{His}_{6}-\mathrm{KDM} 4 \mathrm{~A} / \mathrm{B} / \mathrm{C}$ proteins were desalted with PD-10 desalting columns (GE healthcare, Chicago, IL, USA), then cleaved with $0.005 \mathrm{U}$ thrombin per $\mu \mathrm{g}$ of protein. Proteins without the tag were then purified from the mixture by passing them through the Ni Sepharose 6 fast flow columns again. To overcome nonspecific Ni binding, a stepped elution was performed with elution buffer containing increasing concentrations of imidazole $(0,40,80$, and $250 \mathrm{mM})$. All eluates were analyzed on SDS-PAGE gels.

Heme absorbance spectra were measured with a Varian Cary ${ }^{\circledR} 50$ UV-Vis Spectrophotometer. Samples contained $10 \mu \mathrm{M}$ protein, $5 \mu \mathrm{M}$ heme, and 0, 10, 20, 40, 80, or $160 \mathrm{mM}$ imidazole. Protein and heme were prepared in $20 \mathrm{mM}$ Tris ( $\mathrm{pH} 8.0$ ) and $500 \mathrm{mM} \mathrm{NaCl}$; the imidazole stock was adjusted to $\mathrm{pH} 8.0$ with $\mathrm{HCl}$. Each sample was incubated for $30 \mathrm{~s}$ after the addition of heme prior to absorbance measurement.

To detect protein binding to heme with heme-agarose beads (Sigma, St. Louis, MO, USA), purified proteins were incubated with the beads in the heme binding buffer $(20 \mathrm{mM}$ Tris ( $\mathrm{pH} 8.0), 500 \mathrm{mM} \mathrm{NaCl}$, and $1 \%$ TritonX-100) for $1 \mathrm{~h}$ at $4{ }^{\circ} \mathrm{C}$. After incubation, the beads were pelleted by centrifugation, and the supernatant was collected. The beads were then washed twice with heme-binding buffer. Subsequently, proteins bound to the beads and in the supernatant were electrophoresed on SDS polyacrylamide gels and visualized by Coomassie blue staining.

\subsection{Measurement of KDM4A/B/C and Gis1 Demethylase Activity}

The demethylase activity of purified KDM4A/B/C proteins was measured using an Epigenase Demethylase Activity/Inhibition Assay Kit (EpiGentek, P3081-48), according to the manufacturer's protocol. Briefly, $50 \mathrm{ng}$ of the trimethyl histone H3K9 peptide (Cat. No. R-1028), which was derived from residues within 1-100 of human histone H3, was stably coated onto 96-well microplate wells. 
Enzymatic reactions were set up for blank (without protein) and sample (with $300 \mathrm{ng}$, about 3 pmol, of purified $\mathrm{KDM} 4 \mathrm{~A} / \mathrm{B} / \mathrm{C}$ proteins) in a total volume of $50 \mu \mathrm{L}$, in the presence or absence of $2 \mu \mathrm{M}$ heme. The microplate strip wells were covered with adhesive covering film and incubated at $37^{\circ} \mathrm{C}$ for $120 \mathrm{~min}$. To detect the amount of demethylated product, the wells were washed and incubated with a capture antibody (anti-H3K9 me1) at room temperature for $60 \mathrm{~min}$ followed by incubation with a detection antibody at room temperature for $30 \mathrm{~min}$. The amount of demethylated product was fluorometrically measured with a BioTek Cytation 5-plate reader with excitation and emission wavelengths of $530 \mathrm{~nm}$ and $590 \mathrm{~nm}$, respectively, after adding a fluorescence development solution. Demethylase activity of the protein was calculated in Relative Fluorescence Units (RFU) /min/mg, as described in the manufacturer's protocol.

The demethylase activity of purified Gis1 proteins was measured using a custom-made Epigenase Demethylase Activity/Inhibition Assay Kit (EpiGentek, P3081-48 CUSTOM) with dimethyl histone H3K36 peptide (Cat. No. R-1038) anti-H3K36me1 capture antibody, as described above.

\subsection{Identification of Gis1 Interactors, Mass Spectrometry (MS), and Proteomic Data Analysis}

Yeast cell extracts were prepared according to previously established protocols $[67,68]$. Briefly, yeast cells were grown to an optical density (OD) of 1.0-1.5 in rich medium containing glucose under normoxic, hypoxic, intermediate, and high-heme conditions. The hypoxic $\left(\sim 10 \mathrm{ppb} \mathrm{O}_{2}\right)$ growth condition was created using a hypoxia chamber (Coy Laboratory, Inc.) and it with a mixture of $5 \% \mathrm{H}_{2}$ and $95 \% \mathrm{~N}_{2}$ in the presence of a palladium catalyst [69]. Intermediate and high heme conditions were achieved by growing $\Delta h e m 1$ yeast cells in the presence of intermediate $(50 \mu \mathrm{g} / \mathrm{mL})$ or high $(250 \mu \mathrm{g} / \mathrm{mL})$ levels of ALA. Cells were harvested and resuspended in three packed cell volumes of buffer $(20 \mathrm{mM}$ Tris, $10 \mathrm{mM} \mathrm{MgCl} 2,1 \mathrm{mM}$ Ethylenediaminetetraacetic acid (EDTA), 10\% glycerol, $1 \mathrm{mM}$ dithiothreitol (DTT), $0.3 \mathrm{M} \mathrm{NaCl}, 1 \mathrm{mM}$ phenylmethylsulfonyl fluoride, $1 \mathrm{X}$ protease inhibitors). Cells were then permeabilized by agitation with four packed cell volumes of glass beads and extracts were collected, as previously described [68].

His $_{6}$-Gis1 was pre-bound to a Ni Sepharose 6 Fast Flow column (GE Healthcare, Chicago, IL). To identify the Gis1 interactors, the crude yeast protein extract was loaded onto a Gis1-bound column and incubated at $4{ }^{\circ} \mathrm{C}$ for $2 \mathrm{~h}$. The complexes were then eluted from the column and separated by SDS-PAGE using $12 \%$ polyacrylamide gels followed by Coomassie blue staining. A total of 19 protein bands (see Supplemental Figure S2) were excised with sterile blades and destained twice with $100 \mathrm{mM}$ $\mathrm{NH}_{4} \mathrm{HCO}_{3}$ in $50 \%$ acetonitrile. The samples were prepared following the Penn State Hershey Mass Spectrometry Core facility standard protocol. The Mass Spectrometry (MS) spectra were taken by ABSciex 5600 TripleTOF using samples separated by Eksigent NanoLC-Ultra-2D Plus and Eksigent cHiPLC Nanoflex via $200 \mu \mathrm{m} \times 0.5 \mathrm{~mm}$ chromatography. Multiple proteins were often identified in each band.

ProteinPilot software version 5.0 was used to perform protein identification by searching MS spectra against the species-specific (Saccharomyces. cerevisiae) National Center for Biotechnology Information (NCBI) database sequences, which contains 36,621 protein sequences plus 156 common lab contaminants. Bioinformatics analyses were performed using the paragon algorithm in ProteinPilot 5.0 software (Framingham, MA, USA) to identify the potential proteins interacting with Gis1 by ranking them according to their unused scores. Protein identifications must have a ProteinPilot Unused Score $>1.3$ ( $>95 \%$ confidence interval) in order to be accepted. In addition, the only protein IDs accepted must have a "Local False Discovery Rate" estimation of no higher than $5 \%$, which is a more stringent criterion than the often-used 1\% Global False Discovery Rate. The identified protein list was then uploaded to CRAPome to eliminate potential false positives [70]. Proteins with $p$ values equal to 0 were selected and further analyzed. The total number of unique proteins identified was 148, including Gis1. The proteins were then grouped based on the conditions in which they were identified into various classes (high ALA only, intermediate ALA only, hypoxia only, air only, and a combination of these classes). Further Gene Ontology (GO) analysis of the identified proteins was performed using STRING 
(http://string-db.org/). Human orthologues of the yeast proteins were identified using YeastMine (https://yeastmine.yeastgenome.org/).

\subsection{Preparation of Yeast Extracts, TAP-Pulldown, and Western Blotting}

Yeast cells expressing various TAP-tagged proteins and full-length Gis1 or Gis1 deletion proteins were grown in synthetic complete media to an optical density $(600 \mathrm{~nm})$ of approximately 1.0-1.5. Cells were harvested and extracts were prepared as described previously [71]. For TAP-pulldown, protein extracts were incubated with IgG-Sepharose beads to capture the target proteins. After this binding reaction, the beads were washed to remove unbound proteins, as described [72]. All steps were carried out in the cold room at $4{ }^{\circ} \mathrm{C}$. Input and protein complexes bound to the beads were detected by Western blotting, where $75 \mu \mathrm{g}$ of proteins from each treatment condition were electrophoresed on 10\% SDS-Polyacrylamide gels, then transferred onto an Immuno-Blot PVDF Membrane (Bio-Rad, Hercules, CA, USA). The membranes were probed with antibodies, followed by detection with a chemiluminescent Western blotting kit (Roche Diagnostics, Mannheim, Germany). The signals were detected with a Carestream image station 4000MM Pro and quantitation was performed with the Carestream molecular imaging software version 5.0.5.30 (Carestream Health, Inc., Rochester, NY, USA).

\section{Results}

\subsection{Heme Binds to the JmjN/C Domain of KDM4A/B/C and Regulates the Histone Demethylase Activity of} $K D M 4 A$ and $C$, but not KDM4B

Previously, we showed that the purified JmjN/C domain of Gis1 binds to heme [23]. Here, we purified the JmjN/C domains (Figure 1) of KDM4A/B/C. We used previously well-established heme bead binding and heme spectrum methods $[23,51,73]$ to determine if the JmjN/C domains of KDM4A/B/C bind to heme. First, using heme-agarose beads, we showed that the JmjN/C domains of KDM4A/B/C all bound to heme (Figure 2). For controls, we showed that carbonic anhydrase did not bind to heme agarose (lanes 1-3, Figure 2), as expected [74]. In contrast, both human serum albumin (has) (lanes 4-6, Figure 2) and bovine serum albumin (BSA) (lanes 7-9, Figure 2) bound to heme beads, because they bind to heme directly $[74,75]$. The JmjN/C domains of KDM4A/B/C all bound to heme beads strongly (lanes 10-18, Figure 2). When the JmjN/C domains of KDM4A/B/C were mixed in equal molar amounts with BSA and incubated with heme beads, they bound more strongly than BSA (lanes 19-24, Figure 2). Note that heme attached to the beads via the propionate group, thus, KDM4s do not interact with heme via the propionate group. Second, we examined heme binding to JmjN/C domains by detecting their effect on the major heme absorption band, the Soret band, which is around $400 \mathrm{~nm}$. Like the JmjN/C domain of Gis1 (Figure 3A), JmjN/C domains of KDM4A/B/C (Figure 3B-D) bound to heme and shifted the Soret peak to longer wave lengths (Figure 3A-D, compare lines 1 and 2). The JmjN/C domains of Gis1 and KDM4A/B/C appeared to be purified without heme (Figure 3A-D), while full-length Gis1, which has higher heme-binding affinity than the JmjN/C domain, appeared to be purified with some heme [23]. As shown previously [51], imidazole chelated heme and shifted the Soret peak from about $386 \mathrm{~nm}$ to about $434 \mathrm{~nm}$, and it also enhanced the spectral changes caused by the binding of the JmjN/C domain of Gis1 or KDM4A/B/C (compare lines 3 and 4 in Figure 3A-D). Specifically, in the presence of $10 \mathrm{mM}$ imidazole, binding of the $\mathrm{JmjN} / \mathrm{C}$ domains shifted the heme absorption peak from around 434 $\mathrm{nm}$ to $411 \mathrm{~nm}$ (compare lines 3 and 4 in Figure 3A-D). Figure 3E shows that 10-160 mM imidazole induced very similar heme spectral changes. Using imidazole titration as described previously [23], we found that similar concentrations of imidazole were required to shift the Soret peak to $434 \mathrm{~nm}$ in the presence of JmjN/C domains of KDM4-C compared to that of Gis1 (Supplemental Figure S1). The difference spectra shown in Figure 3A-D further illustrate the change caused by the binding of the JmjN/C domains to heme, particularly in the presence of imidazole, suggesting that the JmjN/C domains of $\mathrm{KDM} 4 \mathrm{~A} / \mathrm{B} / \mathrm{C}$ bound to heme with comparable affinity to the Gis1 JmjN/C domain. 


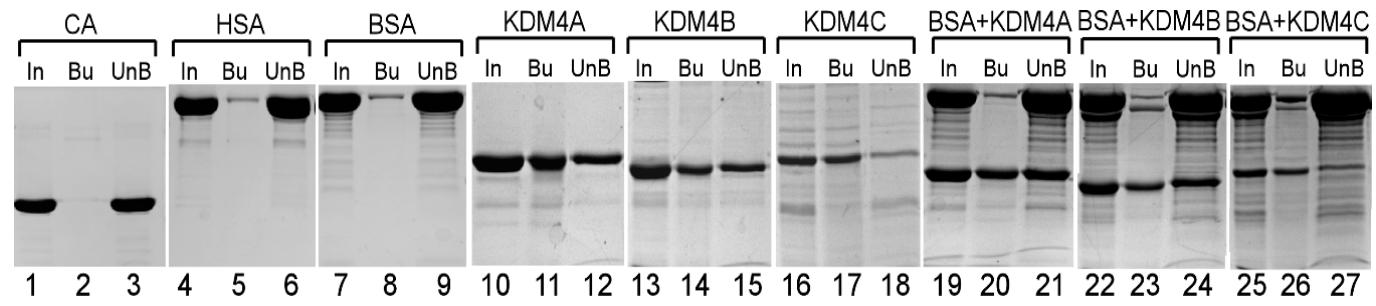

Figure 2. The pull-down of KDM4 JmjN/C domains by heme-agarose beads. Samples containing $500 \mathrm{pm}$ of carbonic anhydrase (CA) (lanes 1-3), human serum albumin (HSA) (lanes 4-6), and bovine serum albumin (BSA) (lanes 7-9), and the JmjN/C domain of KDM4A (lanes 10-12), KDM4B (lanes 13-15), or KDM4C (lanes 16-18), or a mixture of the indicated proteins (500 pm each, lines 19-27) were incubated with heme-agarose beads. The input $(\mathrm{In})$, bound $(\mathrm{Bu})$, and unbound proteins $(\mathrm{UnB})$ were analyzed by SDS-PAGE and are shown here.
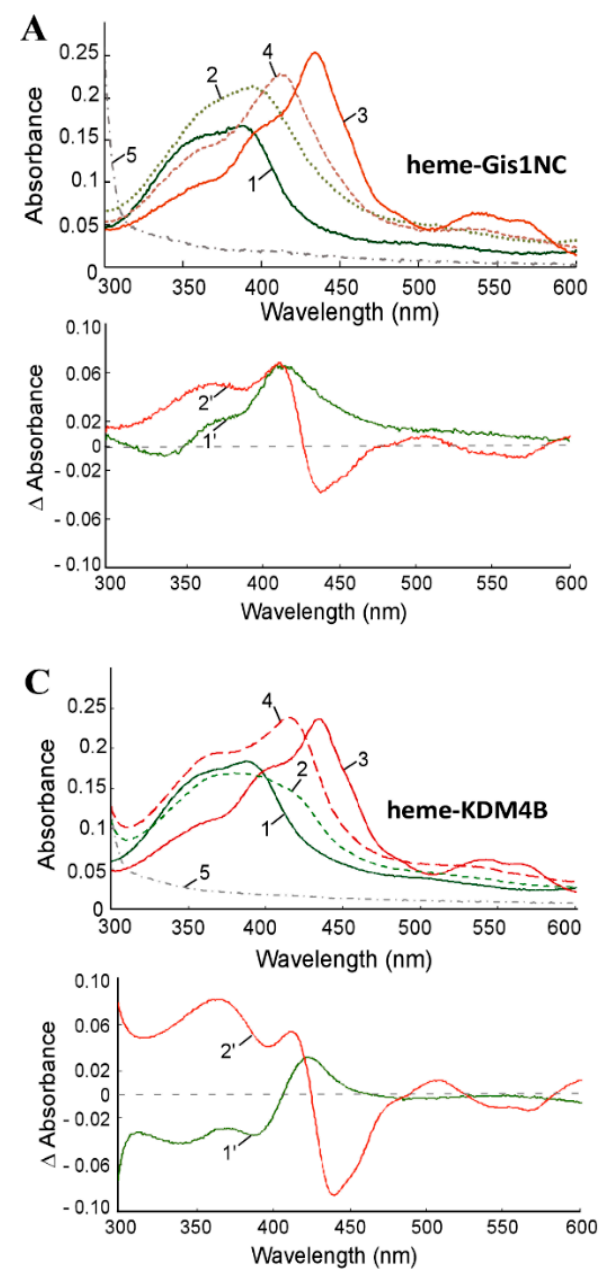

E

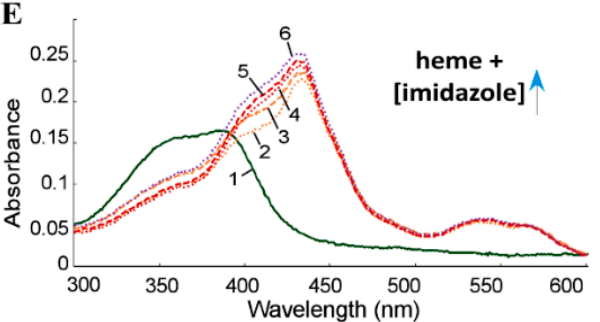

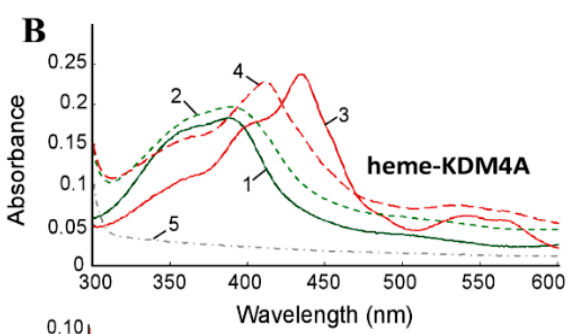

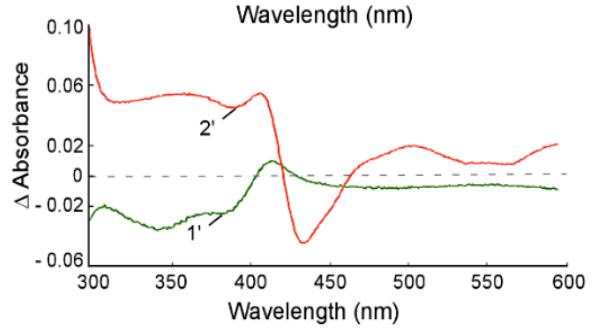

D
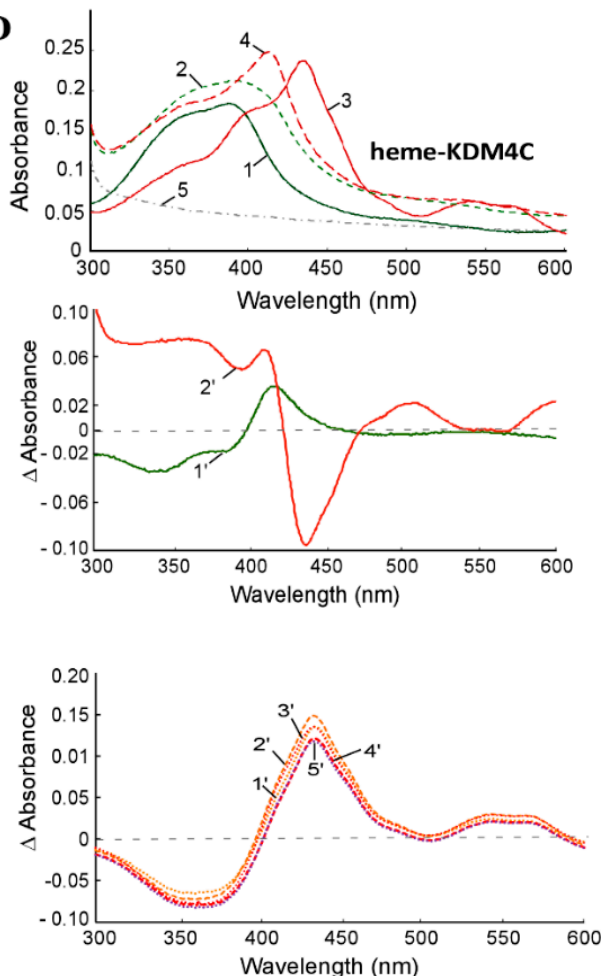

Figure 3. Absorption spectra of heme in the absence and presence of KDM4 JmjN/C domains. (A) Heme 
absorption spectra in the presence of the Gis1 JmjN/C domain (shown for comparison). (B) Heme absorption spectra in the presence of the KDM4A JmjN/C domain. (C) Heme absorption spectra in the presence of the KDM4B JmjN/C domain. (D) Heme absorption spectra in the presence of the KDM4C JmjN/C domain. (E) The effect of increasing concentrations of imidazole on the heme absorption spectrum. (A-D) Line 1: $5 \mu \mathrm{M}$ heme; line 2: $5 \mu \mathrm{M}$ heme $+10 \mu \mathrm{M}$ JmjN/C domain of Gis1 or $\mathrm{KDM} 4 \mathrm{~A} / \mathrm{B} / \mathrm{C}$; line 3: $5 \mu \mathrm{M}$ heme $+10 \mathrm{mM}$ imidazole; line 4: $5 \mu \mathrm{M}$ heme $+10 \mu \mathrm{M} \mathrm{JmjN} / \mathrm{C}$ domain of Gis1 or KDM4A/B/C + $10 \mathrm{mM}$ imidazole; line 5: $10 \mu \mathrm{M}$ JmjN/C domain of Gis1 or KDM4A/B/C. (E) Line 1: $5 \mu \mathrm{M}$ heme; line 2: $5 \mu \mathrm{M}$ heme $+10 \mathrm{mM}$ imidazole; line 3: $5 \mu \mathrm{M}$ heme $+20 \mathrm{mM}$ imidazole; line 4: $5 \mu \mathrm{M}$ heme $+40 \mathrm{mM}$ imidazole; line 5: $5 \mu \mathrm{M}$ heme $+80 \mathrm{mM}$ imidazole; line 6: $5 \mu \mathrm{M}$ heme +160 $\mathrm{mM}$ imidazole. The difference spectra are shown under the heme absorption spectra. (A-D) Line $1^{\prime}$ : (heme + protein) - heme; line 2': (heme + imid + protein) - (heme + imid). E: Line 1': (heme + $10 \mathrm{mM}$ imidazole) - heme; line $2^{\prime}$ : (heme + $20 \mathrm{mM}$ imidazole) - heme; line $3^{\prime}$ : (heme + $40 \mathrm{mM}$ imidazole) heme; line $4^{\prime}$ : (heme + $80 \mathrm{mM}$ imidazole) - heme; line 5': (heme + $160 \mathrm{mM}$ imidazole) - heme.

To determine whether heme binding to KDM4 JmjN/C domains affects their functions, we detected the effect of heme on histone demethylase activity using the well-established Epigenase Demethylase Activity/Inhibition Assay Kit (EpiGentek, Farmingdale, NY, USA). We detected the effect of heme on the activity of purified JmjN/C domains of KDM4A/B/C on H3K9me3. We found that heme strongly potentiated the activity of KDM4A and C, but not KDM4B (Figure 4). For comparison, we showed that heme stimulated the demethylase activity of full-length Gis1, but not the JmjN/C domain, as reported previously [23]. Clearly, the JmjN/C domains of KDM4A and C can mediate heme regulation of their histone demethylase activity, whereas those of KDM4B and Gis1 cannot.

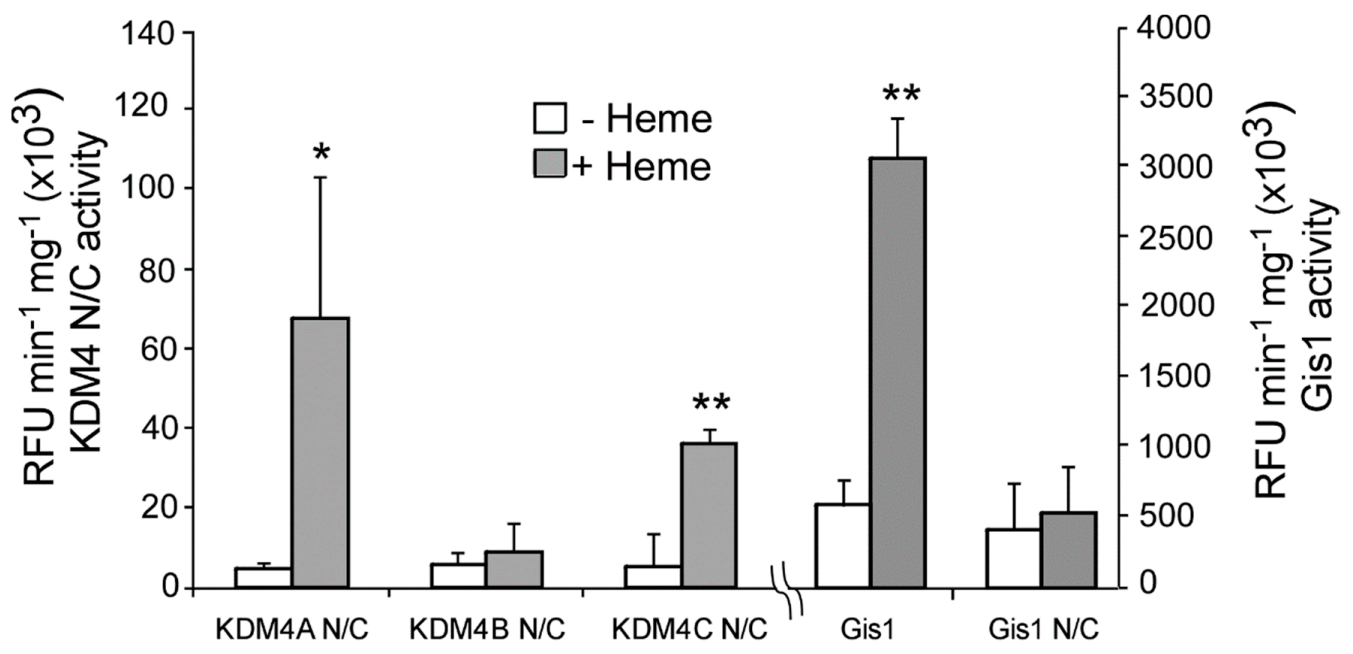

Figure 4. Heme stimulates histone demethylase activities of KDM4A and C, but not KDM4B. The $\mathrm{H} 3 \mathrm{~K} 9 \mathrm{me} 3$ demethylase activities of purified KDM4 JmjN/C domains were measured as described in Section 2 . The assays were repeated multiple times. The data plotted here are averages from at least three replicates. For statistical analysis, the activity in the presence of heme was compared to the activity in the absence of heme with a Welch 2 -sample t-test. ${ }^{*} p$ value $<0.05$; ${ }^{* *} p$ value $<0.005$. The demethylase activities of full-length Gis1 and the Gis1 N/C domain are shown for comparison. 
3.2. The C-terminal Regions of KDM4A/B/C, like that of Gis1, Have the Potential to Modulate the Activity of the JmjN/C Domain and Heme Regulation

Previously, we showed that the C-terminal region of Gis1 containing the zinc finger domain promoted heme regulation when inserted between the DNA-binding and activation domains of a heterologous transcriptional activator Hap1 [23], as shown in Figure 5A,B (see Gis1-Hap1). We also inserted the C-terminal regions containing the PHD and Tudor domains of KDM4A/B/C between the DNA-binding and activation domains of Hap1 (Figure 5A,B). We found that the C-terminal regions of KDM4A, like that of Gis1, strongly promoted heme activation of transcriptional activity, while those of KDM4B and C somewhat promoted heme activation of transcriptional activity (Figure 5B). These results suggested that the C-terminal regions of KDM4A, like that of Gis1, and to a lesser extent, $\mathrm{KDM} 4 \mathrm{~B}$ and $\mathrm{C}$, have the potential to modulate the activity of the JmjN/C domains and heme regulation.

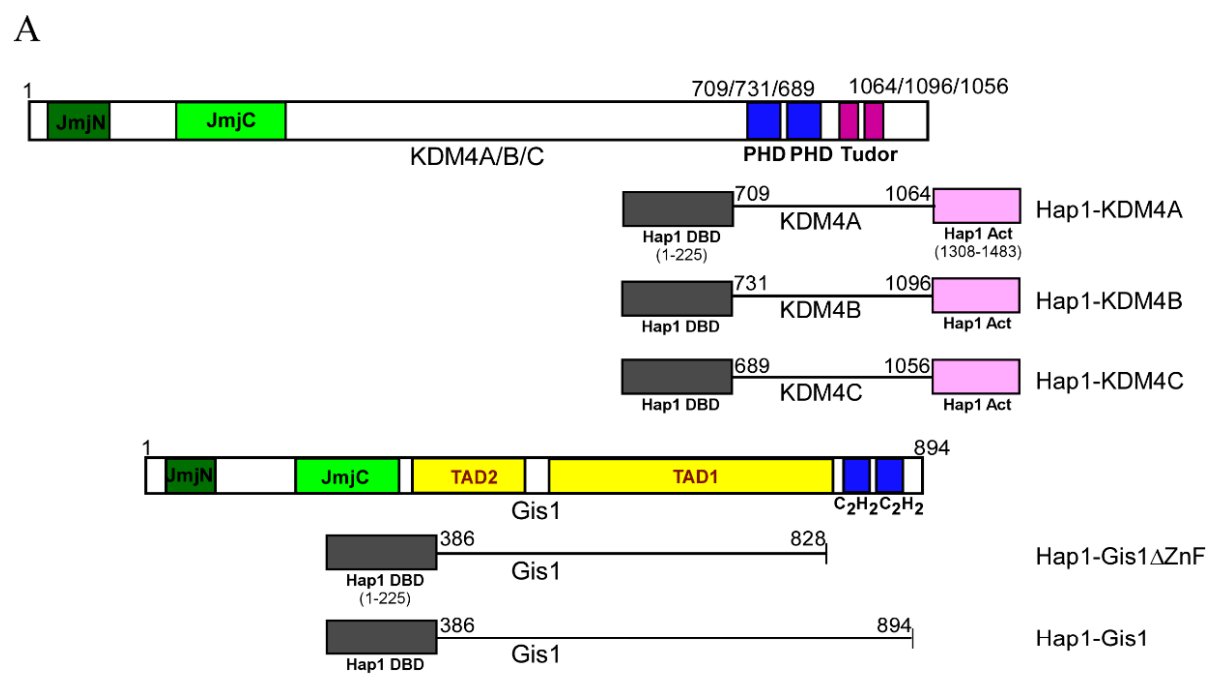

B

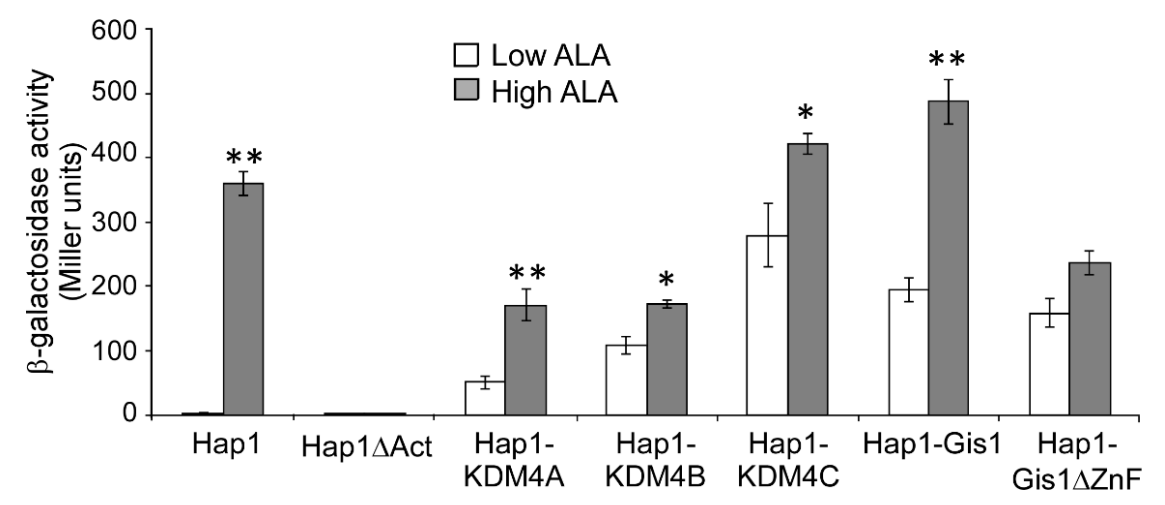

Figure 5. The C-terminal domains of KDM4 proteins can confer heme regulation of transcriptional activity via an unrelated transcription factor. (A) The domain maps of the hybrid proteins are shown. (B) The transcriptional activities of hybrid proteins in yeast cells. Yeast $\Delta$ gis $1 \Delta h e m 1$ cells bearing the expression vector for wild type Hap1, Hap1 $\Delta$ Act lacking the activation domain, Hap1-KDM4A, Hap1-KDM4B, and Hap1-KDM4C fusion protein, as well as the Hap1-binding UAS1-CYC1-lacZ reporter, were grown in the presence of low $(2.5 \mu \mathrm{g} / \mathrm{mL})$ or high $(250 \mu \mathrm{g} / \mathrm{mL})$ levels of ALA. Cells were then collected and $\beta$-galactosidase activities were measured. For statistical analysis, the levels in heme-deficient cells were compared to the levels in heme-sufficient cells with a Welch 2-sample t-test. ${ }^{*} p$ value $<0.05$; ${ }^{* *} p$ value $<0.005$. The activities of Hap1-Gis1 and Hap1-Gis1 $\Delta \mathrm{ZnF}$ are shown for comparison. 


\subsection{Mass Spectrometry (MS) Identified 147 Proteins that can Interact with Gis1 In Vitro}

Gis1, like other KDM4 proteins, is known to interact with many proteins [76]. These proteins may influence Gis1 histone demethylase and transcriptional activities and may promote heme regulation. Furthermore, Gis1 is likely to interact with different proteins under heme-deficient and heme-sufficient conditions. We therefore systematically identified the proteins that interact with Gis1 under heme-deficient and heme-sufficient conditions by coupling biochemical pull-down with mass spectrometry. To this end, we used yeast strains that were fully functional in oxygen and heme signaling [64]. We prepared extracts from $\Delta$ gis1 (to limit preformed Gis1 complexes) cells grown in air or under hypoxic conditions, and $\Delta$ gis $1 \Delta h e m 1$ cells grown at high or intermediate heme levels. We used extracts prepared from hypoxic cells which could not synthesize heme [77] in lieu of heme-deficient cells because proteins are very labile in extracts prepared from heme-deficient cells. To identify Gis1-interacting proteins, extracts were loaded onto columns bound by full-length Gis1 purified from E. coli, and bound proteins were collected and subjected to SDS-PAGE. Protein bands that were retained specifically and only on Gis1-bound beads were excised (see bands shown in Supplemental Figure S2) and identified with mass spectrometry (MS). After extensive statistical and computational analyses (see Section 2), we identified 147 Gis1-interacting protein candidates (see Figure 6A). Several classes of the candidate proteins were worth noting, including 58 proteins that were identified only under hypoxic conditions that may suppress Gis1 activities in heme-deficient cells (see Table 1), 54 proteins that were identified only under high or intermediate levels of ALA or in air (heme-sufficient) that may promote Gis1 activities in heme-sufficient cells (see Table 2), and 36 proteins that were identified under both hypoxic/heme-deficient and heme-sufficient conditions that may both suppress and promote Gis1 activities depending on the heme levels (see Table 3). Seven of the identified Gis1-interacting proteins, Mig1, Snf1, Msc1, Bck1, Kcs1, Rvs167, and Cyr1 interact with Gis1 genetically [34,78-81], strongly supporting the validity of the biochemistry-MS approach used here. To further confirm the results from MS, we carried out co-immunoprecipitation for several identified Gis1-interacting protein candidates. Figure 6B shows that Mot3, Oye2, and PbP4 can be pulled down together specifically with Gis1, which further validates the results from the MS analysis. Interestingly, Figure $6 \mathrm{C}$ also shows that the $\mathrm{ZnF}$ domain of Gis1 is required for interaction with Mot3, while the JmjN/C domain is not necessary for interaction with Mot3. The lower band of the doublets shown in Figure $6 \mathrm{~B}, \mathrm{C}$ are presumably shorter, degraded fragments of the detected proteins lacking part of the $\mathrm{N}$-terminal sequences (tags here are at the C-terminus).

Gene Ontology (GO) analysis of the identified Gis1-interacting proteins revealed several major, statistically significant functional classes, including 68 proteins, such as Gpd2 and Cpa1, that are able bind to heterocyclic compounds, such as nucleotides and nicotinamide adenine dinucleotide (Tables 1-3), 32 Gis1-interacting proteins that are involved in metabolism, such as the glycolytic pathway, the tricarboxylic acid cycle (TCA) cycle, and fatty acid metabolism (see Tables 1-3), 20 interacting proteins that are involved in ubiquitin-like protein ( $\mathrm{Ubl}$ ) conjugation (Tables 1-3), and 22 interacting proteins that are involved in acetylation (Tables 1-3). These results suggest that Gis1 interacts with proteins of many different pathways and potentially influences many molecular and cellular processes. 
A

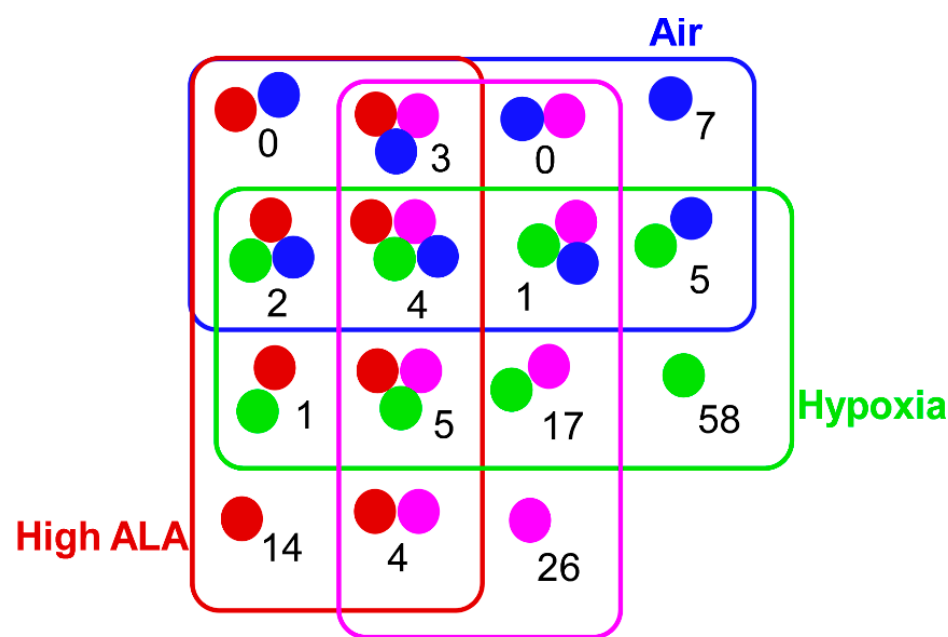

B

Intermediate ALA

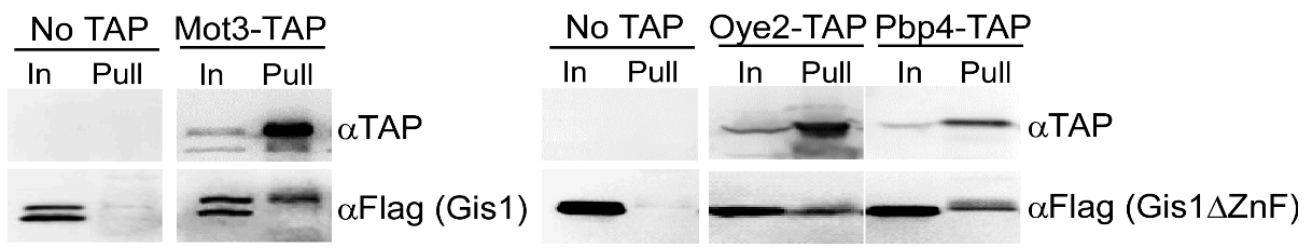

C
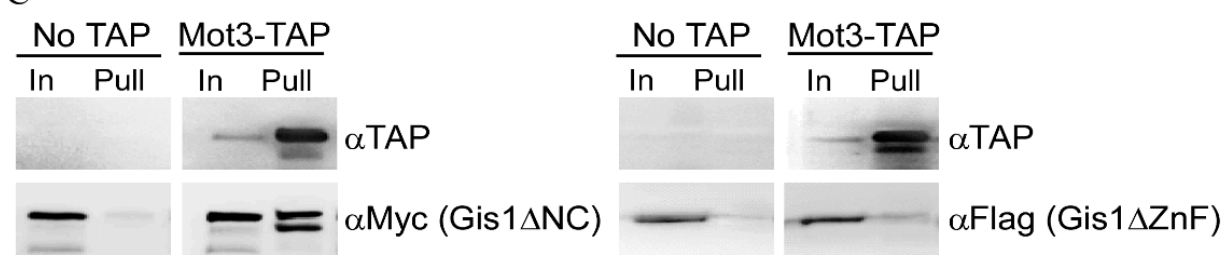

Figure 6. (A) Venn diagrams showing overlaps for Gis1-bound proteins under various conditions. The numbers of proteins bound to Gis1 identified from extracts prepared from cells grown under various conditions are shown here. (B) TAP pull-down confirms that Mot3, Oye2, and Pbp4 interact with Gis1. Extracts prepared from cells expressing TAP-tagged Mot3, Pbp4, or Oye2 and FLAG-tagged Gis1 were incubated with IgG-Sepharose 6 beads. Input proteins (In) and pulled-down (Pull) proteins were electrophoresed and detected by anti-TAP or anti-FLAG antibodies. Blots were probed with anti-TAP antibodies and then stripped and probed with anti-Flag antibodies. (C) The Gis1 ZnF domain, but not the JmjN/C domain, is required for interaction with Mot3. Extracts prepared from cells expressing TAP-tagged Mot3 and FLAG-tagged Gis1 $\triangle \mathrm{ZnF}$ or Myc-tagged Gis1 $\Delta \mathrm{NC}$ were incubated with gG-Sepharose 6 beads. Input proteins (In) and pulled-down (Pull) proteins were electrophoresed and detected by anti-TAP, anti-Myc, or anti-FLAG antibodies. Blots were probed with anti-TAP antibodies and then stripped and probed with anti-Flag or anti-Myc antibodies. 
Table 1. List of bound proteins found only in extracts from hypoxic cells.

\begin{tabular}{|c|c|c|c|c|c|c|c|c|}
\hline $\begin{array}{l}\text { Common } \\
\text { Name }\end{array}$ & $\begin{array}{l}\text { ORF } \\
\text { Name }\end{array}$ & $\begin{array}{l}\text { Protein ID } \\
\text { (gi \#) }\end{array}$ & Description & Human Orthologues & $\mathrm{HCB}^{1}$ & $\mathrm{Mtb}^{2}$ & $\mathrm{Ubl}^{3}$ & Acet $^{4}$ \\
\hline ACT1 & YFL039C & 14318479 & $\begin{array}{l}\text { Structural protein involved } \\
\text { in cell polarization }\end{array}$ & $\begin{array}{c}\text { ACTA1, ACTA2, ACTB, } \\
\text { ACTBL2, ACTC1, } \\
\text { ACTG1, ACTG2, } \\
\text { ACTR1A, ACTR1B, } \\
\text { ACTRT1, ACTRT2, } \\
\text { ACTRT3, POTEE, } \\
\text { POTEKP }\end{array}$ & + & & + & + \\
\hline AHA1 & YDR214W & 398366155 & $\begin{array}{l}\text { Activator of heat-shock } \\
\text { protein } 90 \text { ATPase }\end{array}$ & AHSA1 & & & & \\
\hline AIM6 & YDL237W & 330443495 & $\begin{array}{l}\text { Altered inheritance of } \\
\text { mitochondria protein }\end{array}$ & - & & & & \\
\hline ARC40 & YBR234C & 6319711 & $\begin{array}{l}\text { Subunit of the ARP2/3 } \\
\text { complex }\end{array}$ & ARPC1A, ARPC1B & & & & \\
\hline BCK1 & YJL095W & 6322366 & $\begin{array}{l}\text { Serine/threonine protein } \\
\text { kinase }\end{array}$ & $\begin{array}{c}\text { MAP3K1, MAP3K2, } \\
\text { MAP3K3, NRBP1, } \\
\text { NRBP2, WNK1, WNK2, } \\
\text { WNK3, WNK4 }\end{array}$ & + & & & \\
\hline CAF20 & YOR276W & 398366043 & $\begin{array}{c}\text { Cap-associated } \\
\text { phosphoprotein of the } \\
\text { mRNA cap-binding } \\
\text { complex }\end{array}$ & 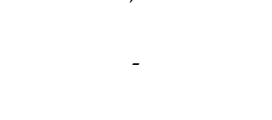 & + & & & \\
\hline CDC33 & YOL139C & 6324433 & $\begin{array}{l}\text { mRNA cap binding protein } \\
\text { and translation initiation } \\
\text { factor }\end{array}$ & EIF4E, EIF4E2, EIF4E3 & + & & + & \\
\hline CKS1 & YBR135W & 398364999 & $\begin{array}{c}\text { Cyclin-dependent protein } \\
\text { kinase regulatory subunit } \\
\text { and adaptor }\end{array}$ & CKS1B, CKS2 & & & & \\
\hline CPR1 & YDR155C & 6320359 & $\begin{array}{c}\text { Cytoplasmic } \\
\text { peptidyl-prolyl cis-trans } \\
\text { isomerase }\end{array}$ & $\begin{array}{l}\text { PPIA, PPIAL4E, PPIE, } \\
\text { PPIF, RANBP2, RGPD1, } \\
\text { RGPD3, RGPD4, } \\
\text { RGPD5, RGPD6 }\end{array}$ & + & & + & + \\
\hline CYR1 & YJL005W & 398364701 & Adenylate cyclase & $\begin{array}{l}\text { LRCH1, LRR1, LRRC59, } \\
\text { LRRK1, PHLPP1, } \\
\text { PHLPP2 }\end{array}$ & + & & & + \\
\hline DIG1 & YPL049C & 6325208 & $\begin{array}{l}\text { Downregulator of invasive } \\
\text { growth }\end{array}$ & - & + & & & \\
\hline DOT6 & YER088C & 398364577 & $\begin{array}{l}\text { Disruptor of telomeric } \\
\text { silencing }\end{array}$ & - & + & & & \\
\hline ERG6 & YML008C & 6323635 & $\begin{array}{c}\text { Delta(24)-sterol } \\
\text { C-methyltransferase }\end{array}$ & COQ3, WBSCR27 & & + & & + \\
\hline ESS1 & YJR017C & 37362669 & $\begin{array}{l}\text { Peptidyl-prolyl cis-trans } \\
\text { isomerase }\end{array}$ & PIN1 & & & & \\
\hline GOR1 & YNL274C & 6325144 & $\begin{array}{c}\text { Glyoxylate reductase } \\
\text { Mitochondrial }\end{array}$ & GRHPR & + & + & & \\
\hline GPD2 & YOL059W & 6324513 & $\begin{array}{c}\text { glycerol-3-phosphate } \\
\text { dehydrogenase (NAD }(+)) 2\end{array}$ & GPD1 & + & + & & \\
\hline GRX2 & YDR513W & 6320720 & $\begin{array}{l}\text { Mitochondrial } \\
\text { glutaredoxin-2 }\end{array}$ & GLRX, GLRX2 & & & & \\
\hline GYP1 & YOR070C & 6324644 & $\begin{array}{c}\text { Cis-golgi GTPase-activating } \\
\text { protein (GAP) for yeast } \\
\text { Rabs }\end{array}$ & - & & & & \\
\hline HIT1 & YJR055W & 6322515 & $\begin{array}{l}\text { Protein involved in C/D } \\
\text { snoRNP assembly }\end{array}$ & ZNHIT3 & & & & \\
\hline HPA3 & YEL066W & 6320768 & $\begin{array}{c}\text { D-amino-acid } \\
\text { N-acetyltransferase }\end{array}$ & 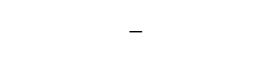 & & & & + \\
\hline HTB2 & YBL002W & 6319471 & $\begin{array}{c}\text { Core histone protein } \\
\text { required for chromatin } \\
\text { assembly and chromosome } \\
\text { function }\end{array}$ & $\begin{array}{c}\text { H2BFWT, HIST1H2BA, } \\
\text { HIST1H2BB, } \\
\text { HIST1H2BC, } \\
\text { HIST1H2BD, } \\
\text { HIST1H2BE, } \\
\text { HIST1H2BF, } \\
\text { HIST1H2BG, } \\
\text { HIST1H2BH, } \\
\text { HIST1H2BI, HIST1H2BJ, } \\
\text { HIST1H2BK, } \\
\text { HIST1H2BL, } \\
\text { HIST1H2BM, } \\
\text { HIST1H2BN, } \\
\text { HIST1H2BO, } \\
\text { HIST2H2BE, } \\
\text { HIST3H2BB }\end{array}$ & + & & + & + \\
\hline
\end{tabular}


Table 1. Cont.

\begin{tabular}{|c|c|c|c|c|c|c|c|c|}
\hline $\begin{array}{l}\text { Common } \\
\text { Name }\end{array}$ & $\begin{array}{l}\text { ORF } \\
\text { Name }\end{array}$ & $\begin{array}{l}\text { Protein ID } \\
\quad \text { (gi \#) }\end{array}$ & Description & Human Orthologues & НСB $^{1}$ & $\mathbf{M t b}^{2}$ & $\mathrm{Ubl}^{3}$ & Acet ${ }^{4}$ \\
\hline IMP2 & YMR035-W & 398364225 & $\begin{array}{l}\text { Catalytic subunit of } \\
\text { mitochondrial inner } \\
\text { membrane peptidase } \\
\text { complex }\end{array}$ & IMMP2L & & & & \\
\hline KCS1 & YDR017C & 398365025 & $\begin{array}{l}\text { Inositol hexakisphosphate } \\
\text { and inositol } \\
\text { heptakisphosphate kinase }\end{array}$ & $\begin{array}{l}\text { IP6K1, IP6K2, IP6K3, } \\
\text { IPMK }\end{array}$ & + & + & & \\
\hline MHP1 & YJL042W & 6322419 & MAP-homologous protein & $\begin{array}{c}\text { CARD8, CIITA, NLRC3, } \\
\text { NLRC5, NLRP1, } \\
\text { NLRP10, NLRP11, } \\
\text { NLRP12, NLRP13, } \\
\text { NLRP14, NLRP2, } \\
\text { NLRP3, NLRP4, NLRP5, } \\
\text { NLRP6, NLRP7, NLRP9, } \\
\text { NLRX1, NOD1, NOD2 }\end{array}$ & & & + & + \\
\hline MIG1 & YGL035C & 6321403 & $\begin{array}{l}\text { Transcription factor } \\
\text { involved in glucose } \\
\text { repression }\end{array}$ & $\begin{array}{l}\text { EGR1, EGR2, EGR3, } \\
\text { EGR4, WT1 }\end{array}$ & + & & & \\
\hline MOT2 & YER068W & 398364501 & $\begin{array}{l}\text { General negative regulator } \\
\text { of transcription subunit }\end{array}$ & CNOT4 & + & & + & \\
\hline MRM1 & YOR201C & 398365713 & $\begin{array}{l}\text { Mitochondrial rRNA } \\
\text { methyltransferase }\end{array}$ & - & + & & & \\
\hline MRPL32 & YCR003W & 6319848 & $\begin{array}{l}\text { Mitochondrial ribosomal } \\
\text { protein of the large subunit }\end{array}$ & MRPL32 & & & & \\
\hline MRPS12 & YNR036C & 6324364 & $\begin{array}{l}\text { Mitochondrial ribosomal } \\
\text { protein of the small subunit }\end{array}$ & MRPS12 & & & & \\
\hline MSC3 & YLR219W & 6323248 & $\begin{array}{l}\text { Meiotic sister chromatid } \\
\text { recombination protein }\end{array}$ & - & & & & \\
\hline NBA1 & YOL070C & 6324502 & $\begin{array}{l}\text { Protein of unknown } \\
\text { function }\end{array}$ & - & & & & \\
\hline NUP60 & YAR002W & 6319318 & $\begin{array}{l}\text { Component of central core } \\
\text { of the nuclear pore complex }\end{array}$ & - & & & & \\
\hline OSH3 & YHR073W & 6321864 & $\begin{array}{c}\text { Member of an } \\
\text { oxysterol-binding protein } \\
\text { family }\end{array}$ & $\begin{array}{l}\text { OSBPL3, OSBPL6, } \\
\text { OSBPL7 }\end{array}$ & & & & \\
\hline OYE2 & YHR179W & 6321973 & NADPH dehydrogenase & - & + & & & \\
\hline PBP4 & YDL053C & 6320150 & Pbp1p-binding protein & - & & & & \\
\hline PDI1 & YCL043C & 6319806 & Protein disulfide isomerase & $\begin{array}{l}\text { ERP27, ERP44, P4HB, } \\
\text { PDIA2, PDIA3, TMX3 }\end{array}$ & & & & \\
\hline PGA2 & YNL149C & 6324180 & $\begin{array}{l}\text { Essential protein required } \\
\text { for maturation of Gas1p } \\
\text { and Pho8p }\end{array}$ & - & & & & + \\
\hline PGI1 & YBR196C & 6319673 & $\begin{array}{c}\text { Glycolytic enzyme } \\
\text { phosphoglucose isomerase }\end{array}$ & GPI & & + & & + \\
\hline PGK1 & YCR012W & 10383781 & 3-phosphoglycerate kinase & PGK1, PGK2 & + & + & + & + \\
\hline PHO8 & YDR481C & 398366635 & $\begin{array}{l}\text { Repressible vacuolar } \\
\text { alkaline phosphatase }\end{array}$ & $\begin{array}{l}\text { ALPI, ALPL, ALPP, } \\
\text { ALPPL2 }\end{array}$ & & + & & \\
\hline POL4 & YCR014C & 7839197 & $\begin{array}{l}\text { DNA polymerase IV } \\
\text { Asn-rich cytoplasmic }\end{array}$ & DNTT, POLL, POLM & + & & & \\
\hline PSP2 & YML017W & 41629688 & $\begin{array}{c}\text { protein containing RGG } \\
\text { motifs }\end{array}$ & - & + & & & \\
\hline PTC4 & YBR125C & 6319601 & $\begin{array}{c}\text { Cytoplasmic type } 2 \mathrm{C} \\
\text { protein phosphatase (PP2C) }\end{array}$ & PPM1D, PPM1G & & & & \\
\hline RPS18A & YDR450W & 6320658 & $\begin{array}{c}\text { Protein component of the } \\
\text { small (40S) ribosomal } \\
\text { subunit }\end{array}$ & RPS18 & + & & & \\
\hline SIP1 & YDR422C & 398366583 & $\begin{array}{l}\text { Alternate beta-subunit of } \\
\text { the Snf1p kinase complex }\end{array}$ & - & & & & \\
\hline SNX41 & YDR425W & 6320633 & Sorting nexin & SNX4 & & & & \\
\hline SPC42 & YKL042W & 398364591 & $\begin{array}{l}\text { Central plaque component } \\
\text { of spindle pole body }\end{array}$ & - & & & & \\
\hline SSD1 & YDR293C & 6320499 & $\begin{array}{l}\text { Translational repressor with } \\
\text { a role in polar growth and } \\
\text { wall integrity }\end{array}$ & DIS3L2 & + & & & + \\
\hline TMC1 & YOR052C & 6324626 & $\begin{array}{l}\text { AN1-type zinc finger } \\
\text { protein, effector of } \\
\text { proteotoxic stress response }\end{array}$ & - & & & & + \\
\hline TOD6 & YBL054W & 6319417 & $\begin{array}{l}\text { Twin of dot6p } \\
\text { Covalently bound cell wall }\end{array}$ & - & + & & & \\
\hline TOS1 & YBR162C & 6319638 & $\begin{array}{l}\text { protein of unknown } \\
\text { function }\end{array}$ & - & & & & \\
\hline
\end{tabular}


Table 1. Cont.

\begin{tabular}{|c|c|c|c|c|c|c|c|c|}
\hline $\begin{array}{l}\text { Common } \\
\text { Name }\end{array}$ & $\begin{array}{l}\text { ORF } \\
\text { Name }\end{array}$ & $\begin{array}{l}\text { Protein ID } \\
\quad \text { (gi \#) }\end{array}$ & Description & Human Orthologues & НСВ ${ }^{1}$ & $\mathrm{Mtb}^{2}$ & $\mathrm{Ubl}^{3}$ & Acet ${ }^{4}$ \\
\hline UTR1 & YJR049C & 6322509 & ATP-NADH kinase & NADK & + & + & & \\
\hline YBL081W & YBL081W & 6319390 & Uncharacterized protein & - & & & & \\
\hline YCL020W & YCL020W & 10383771 & $\begin{array}{l}\text { Retrotransposon TYA Gag } \\
\text { gene co-transcribed with } \\
\text { TYB Pol }\end{array}$ & - & + & & & \\
\hline YDR365-WB & YDR365WB & 7839164 & $\begin{array}{l}\text { Retrotransposon TYA Gag } \\
\text { and TYB Pol genes }\end{array}$ & - & & & & \\
\hline YPK2 & YMR104C & 6323751 & $\begin{array}{l}\text { Serine/threonine protein } \\
\text { kinase }\end{array}$ & $\begin{array}{c}\text { AKT1, AKT2, AKT3, } \\
\text { PRKCA, PRKCB, } \\
\text { PRKCD, PRKCE, } \\
\text { PRKCG, PRKCH, } \\
\text { PRKCI, PRKCQ, } \\
\text { PRKCZ, RPS6KB1, } \\
\text { RPS6KB2, SGK1, SGK2, } \\
\text { SGK3 }\end{array}$ & + & + & & \\
\hline YPL247C & YPL247C & 6325009 & $\begin{array}{l}\text { WD repeat-containing } \\
\text { protein }\end{array}$ & & & & & \\
\hline ZDS1 & YMR273C & 6323929 & $\begin{array}{l}\text { Protein with a role in } \\
\text { regulating } \\
\text { Swe1p-dependent } \\
\text { polarized growth }\end{array}$ & - & & & & \\
\hline
\end{tabular}

${ }^{1}$ Heterocyclic compound binding; ${ }^{2}$ metabolism; ${ }^{3}$ Ubl conjugation; ${ }^{4}$ acetylation.

Table 2. List of bound proteins found only in extracts from normoxic or heme-sufficient cells.

\begin{tabular}{|c|c|c|c|c|c|c|c|c|}
\hline $\begin{array}{l}\text { Common } \\
\text { Name }\end{array}$ & ORF Name & $\begin{array}{l}\text { Protein ID } \\
\quad \text { (gi \#) }\end{array}$ & Description & Human Orthologues & $\mathrm{HCB}^{1}$ & $\mathbf{M t b}^{2}$ & $\mathrm{Ubl}^{3}$ & Acet $^{4}$ \\
\hline ADE1 & YAR015W & 6319326 & $\begin{array}{l}\text { Phosphoribosylaminoimidazole- } \\
\text { succinocarboxamide synthase }\end{array}$ & PAICS & + & + & & + \\
\hline $\mathrm{ADH} 3$ & YMR083-W & 6323729 & $\begin{array}{c}\text { Mitochondrial alcohol } \\
\text { dehydrogenase isozyme III }\end{array}$ & SORD, TP53I3 & & + & & \\
\hline AGE1 & YDR524C & 398366675 & $\begin{array}{l}\text { ADP-ribosylation factor (ARF) } \\
\text { GTPase activating protein } \\
\text { (GAP) effector }\end{array}$ & $\begin{array}{c}\text { ACAP1, ACAP2, } \\
\text { AGAP1, AGAP2, } \\
\text { ARAP1, ARAP2, } \\
\text { ARAP3, ASAP1, ASAP2, } \\
\text { ASAP3 }\end{array}$ & & & & \\
\hline ALT1 & YLR089C & 6323118 & $\begin{array}{c}\text { Alanine transaminase (glutamic } \\
\text { pyruvic transaminase) }\end{array}$ & $\begin{array}{c}\text { CCBL1, CCBL2, GPT, } \\
\text { GPT2 }\end{array}$ & + & + & & \\
\hline ATG18 & YFR021W & 16740527 & Autophagy-related protein & WIPI1, WIPI2 & & & & \\
\hline AYR1 & YIL124W & 398364253 & $\begin{array}{c}\text { Bifunctional triacylglycerol } \\
\text { lipase and 1-acyl DHAP } \\
\text { reductase }\end{array}$ & $\begin{array}{c}\text { DECR1, DHRS7, } \\
\text { DHRS7B, DHRS7C, } \\
\text { HSD11B1, HSD17B2 }\end{array}$ & & & & \\
\hline BOI1 & YBL085W & 6319386 & $\begin{array}{l}\text { Protein implicated in polar } \\
\text { growth }\end{array}$ & $\begin{array}{l}\text { NEB, NEBL, PSD, PSD4, } \\
\text { SH3RF2 }\end{array}$ & & & & \\
\hline BRE2 & YLR015W & 6323043 & $\begin{array}{l}\text { Subunit of COMPASS (Set1C) } \\
\text { complex }\end{array}$ & ASH2L & + & & & \\
\hline BUD5 & YCR038C & 10383799 & $\begin{array}{l}\text { Bud site selection protein } \\
\text { Protein involved in cytochrome }\end{array}$ & RAPGEF1, SOS1, SOS2 & & & & \\
\hline COA6 & YMR244C-A & 6323902 & $\begin{array}{l}\text { c oxidase (Complex IV) } \\
\text { assembly }\end{array}$ & COA6 & & & & \\
\hline CPA1 & YOR303W & 398366173 & $\begin{array}{l}\text { Carbamoyl-phosphate synthase } \\
\text { arginine-specific small chain }\end{array}$ & CAD, CPS1, OTC & + & + & & \\
\hline ERG26 & YGL001C & 6321437 & $\begin{array}{l}\text { Sterol-4-alpha-carboxylate } \\
\text { 3-dehydrogenase }\end{array}$ & $\begin{array}{l}\text { GMDS, HSD3B1, } \\
\text { HSD3B2, HSD3B7, } \\
\text { NSDHL }\end{array}$ & & + & & \\
\hline ERV41 & YML067C & 6323573 & $\begin{array}{l}\text { Protein localized to } \\
\text { COPII-coated vesicles }\end{array}$ & ERGIC2 & & & & \\
\hline GIS2 & YNL255C & 6324074 & $\begin{array}{l}\text { Translational activator for } \\
\text { mRNAs with internal ribosome } \\
\text { entry sites }\end{array}$ & CNBP & + & & & \\
\hline GVP36 & YIL041W & 398364435 & BAR domain protein & TAF7, TAF7L, FECH & & & + & + \\
\hline HEM15 & YOR176W & 398365579 & Ferrochelatase & FECH & & + & & \\
\hline HFD1 & YMR110C & 6323757 & Fatty aldehyde dehydrogenase & $\begin{array}{l}\text { ALDH3A1, ALDH3A2, } \\
\text { ALDH3B1, ALDH3B2 }\end{array}$ & & + & & \\
\hline
\end{tabular}


Table 2. Cont.

\begin{tabular}{|c|c|c|c|c|c|c|c|c|}
\hline $\begin{array}{l}\text { Common } \\
\text { Name }\end{array}$ & ORF Name & $\begin{array}{l}\text { Protein ID } \\
\text { (gi \#) }\end{array}$ & Description & Human Orthologues & $\mathrm{HCB}^{1}$ & $\mathrm{Mtb}^{2}$ & $\mathrm{Ubl}^{3}$ & Acet $^{4}$ \\
\hline HSP42 & YDR171W & 6320376 & $\begin{array}{l}\text { Small heat-shock protein } \\
\text { (sHSP) with chaperone activity }\end{array}$ & - & & & & \\
\hline INA22 & YIR024C & 6322215 & $\begin{array}{l}\text { Inner membrane assembly } \\
\text { complex subunit } 22\end{array}$ & - & & & & \\
\hline IPP1 & YBR011C & 6319483 & $\begin{array}{l}\text { Cytoplasmic inorganic } \\
\text { pyrophosphatase }\end{array}$ & PPA1, PPA2 & & & + & \\
\hline IRC22 & YEL001C & 6320836 & $\begin{array}{l}\text { Increased recombination } \\
\text { centers protein }\end{array}$ & - & & & & \\
\hline IRC5 & YFR038W & 42742173 & $\begin{array}{c}\text { Uncharacterized } \\
\text { ATP-dependent helicase }\end{array}$ & HELLS, SMARCAL1 & + & & & \\
\hline LYS12 & YIL094C & 6322097 & $\begin{array}{c}\text { Mitochondrial homoisocitrate } \\
\text { dehydrogenase }\end{array}$ & IDH3A & + & + & & \\
\hline LYS20 & YDL182W & 6320019 & Homocitrate synthase isozyme & HMGCL & & + & & \\
\hline LYS21 & YDL131W & 6320071 & $\begin{array}{l}\text { Mitochondrial homocitrate } \\
\text { synthase }\end{array}$ & HMGCL & & + & & \\
\hline MIG3 & YER028C & 6320866 & Transcription corepressor & $\begin{array}{l}\text { EGR1, EGR2, EGR3, } \\
\text { EGR4, WT1 }\end{array}$ & + & & & \\
\hline MLF3 & YNL074C & 398365051 & $\begin{array}{l}\text { Serine-rich protein of unknown } \\
\text { function }\end{array}$ & - & & & & \\
\hline MPE1 & YKL059C & 6322791 & $\begin{array}{c}\text { Essential conserved subunit of } \\
\text { CPF cleavage and } \\
\text { polyadenylation factor }\end{array}$ & RBBP6 & + & & & \\
\hline MSC1 & YML128C & 6323507 & Protein of unknown function & - & & & & \\
\hline NAM9 & YNL137C & 398364685 & $37 \mathrm{~S}$ ribosomal protein & - & + & & & \\
\hline NPA3 & YJR072C & 398365155 & GPN-loop GTPase & GPN1 & + & & + & \\
\hline OSM1 & YJR051W & 6322511 & Fumarate reductase & SDHA & & & & \\
\hline PHB2 & YGR231C & 50593217 & Prohibitin & PHB2 & & & & \\
\hline PNO1 & YOR145C & 6324720 & $\begin{array}{l}\text { Pre-rRNA-processing protein } \\
\text { Nuclear and cytoplasmic }\end{array}$ & - & + & & & \\
\hline PUB1 & YNL016W & 6324312 & $\begin{array}{c}\text { polyadenylated RNA-binding } \\
\text { protein }\end{array}$ & RBM42, TIA1 & + & & & + \\
\hline RNH1 & YMR234W & 6323890 & Ribonuclease & RNASEH1 & & & & \\
\hline RPC40 & YPR110C & 6325367 & RNA polymerase subunit AC40 & POLR1C & + & & & + \\
\hline RRP3 & YHR065C & 37362659 & $\begin{array}{l}\text { ATP-dependent rRNA helicase } \\
\text { Protein involved in the }\end{array}$ & DDX28, DDX47 & + & & & \\
\hline RSA1 & YPL193W & 6325063 & $\begin{array}{c}\text { assembly of } 605 \text { ribosomal } \\
\text { subunits }\end{array}$ & NUFIP1 & & & & + \\
\hline RTN1 & YDR233C & 398366209 & Reticulon-like protein 1 & $\begin{array}{l}\text { RTN1, RTN2, RTN3, } \\
\text { RTN4 }\end{array}$ & & & & \\
\hline RVS167 & YDR388W & 6320596 & $\begin{array}{l}\text { Calmodulin-binding } \\
\text { actin-associated protein }\end{array}$ & ( & & & + & + \\
\hline SCS2 & YER120W & 398364741 & Integral ER membrane protein & $\begin{array}{l}\text { MOSPD3, VAPA, VAPB } \\
\text { CD180, CNTRL, }\end{array}$ & & & & + \\
\hline SDS22 & YKL193C & 6322655 & $\begin{array}{l}\text { Regulatory subunit of the type } \\
1 \text { protein phosphatase }\end{array}$ & $\begin{array}{l}\text { DNAAF1, LRRC32, } \\
\text { NRROS, PPP1R7, TLR2, } \\
\text { TLR3, TLR4, TLR5, } \\
\text { TLR7 }\end{array}$ & & & & \\
\hline SHE1 & YBL031W & 6319440 & Mitotic spindle protein & - & & & & \\
\hline SIP2 & YGL208W & 6321230 & $\begin{array}{l}\text { One of three beta subunits of } \\
\text { the Snf1 kinase complex }\end{array}$ & PRKAB1, PRKAB2 & & + & & \\
\hline SNF4 & YGL115W & 6321323 & $\begin{array}{l}\text { Activating gamma subunit of } \\
\text { the AMP-activated Snf1p } \\
\text { kinase complex }\end{array}$ & $\begin{array}{l}\text { PRKAG1, PRKAG2, } \\
\text { PRKAG3 }\end{array}$ & + & + & & \\
\hline SOK1 & YDR006C & 398364967 & Protein of unknown function & TCP11 & & & & \\
\hline SRB4 & YER022W & 6320860 & $\begin{array}{l}\text { Subunit of the RNA polymerase } \\
\text { II mediator complex }\end{array}$ & MED17 & + & & & \\
\hline SSO1 & YPL232W & 6325024 & Plasma membrane t-SNARE & $\begin{array}{l}\text { STX11, STX12, STX17, } \\
\text { STX1A, STX1B, STX2, } \\
\text { STX3, STX4, STX7 }\end{array}$ & & & & \\
\hline SUA7 & YPR086W & 6325343 & Transcription factor TFIIB & GTF2B & & & & \\
\hline TDH1 & YJL052W & 398364523 & $\begin{array}{l}\text { Glyceraldehyde-3-phosphate } \\
\text { dehydrogenase }\end{array}$ & GAPDH, GAPDHS & + & + & & \\
\hline VMA13 & YPR036W & 6325293 & $\begin{array}{l}\text { Subunit } \mathrm{H} \text { of the V1 peripheral } \\
\text { membrane domain of V-ATPase }\end{array}$ & ATP6V1H & & & & \\
\hline YBL086C & YBL086C & 6319385 & Uncharacterized protein & FAM102A & & & & \\
\hline YCR087C-A & YCR087C-A & 6319930 & $\begin{array}{l}\text { Putative protein of unknown } \\
\text { function }\end{array}$ & - & + & & & \\
\hline
\end{tabular}

${ }^{1}$ Heterocyclic compound binding; ${ }^{2}$ metabolism; ${ }^{3}$ Ubl conjugation; ${ }^{4}$ acetylation. 
Table 3. List of bound proteins found in extracts from both hypoxic and normoxic or heme-sufficientcells.

\begin{tabular}{|c|c|c|c|c|c|c|c|c|}
\hline $\begin{array}{l}\text { Common } \\
\text { Name }\end{array}$ & $\begin{array}{l}\text { ORF } \\
\text { Name }\end{array}$ & $\begin{array}{l}\text { Protein ID } \\
\text { (gi\#) }\end{array}$ & Description & Human Orthologues & НСВ ${ }^{1}$ & Mtb $^{2}$ & $\mathrm{Ubl}^{3}$ & Acet $^{4}$ \\
\hline ATP1 & YBL099W & 330443397 & $\begin{array}{l}\text { Alpha subunit of the F1 } \\
\text { sector of mitochondrial } \\
\text { F1F0 ATP synthase }\end{array}$ & ATP5A1, ATP5B & + & + & & \\
\hline BEM2 & YER155C & 398364959 & GTPase-activating protein & $\begin{array}{c}\text { ARHGAP10, } \\
\text { ARHGAP12, } \\
\text { ARHGAP15, } \\
\text { ARHGAP21, } \\
\text { ARHGAP23, } \\
\text { ARHGAP26, } \\
\text { ARHGAP27, } \\
\text { ARHGAP35, } \\
\text { ARHGAP42, } \\
\text { ARHGAP9, CHN1, } \\
\text { CHN2, GMIP, HMHA1, } \\
\text { OPHN1, RACGAP1 }\end{array}$ & + & & + & \\
\hline DBP5 & YOR046C & 6324620 & $\begin{array}{c}\text { Cytoplasmic } \\
\text { ATP-dependent RNA } \\
\text { helicase of the DEAD-box } \\
\text { family }\end{array}$ & DDX19B, DDX25 & + & & & \\
\hline DLD3 & YEL071W & 6320764 & $\begin{array}{c}\text { D-2-hydroxyglutarate- } \\
\text { pyruvate transhydrogenase }\end{array}$ & $\begin{array}{l}\text { AGPS, D2HGDH, } \\
\text { LDHD }\end{array}$ & + & + & + & \\
\hline DUF1 & YOL087C & 6324485 & $\begin{array}{l}\text { Uncharacterized WD } \\
\text { repeat-containing protein }\end{array}$ & WDR48 & & & & \\
\hline ERG11 & YHR007C & 6321795 & $\begin{array}{c}\text { Lanosterol } \\
\text { 14-alpha-demethylase }\end{array}$ & CYP51A1 & + & + & + & \\
\hline GAL83 & YER027C & 6320865 & $\begin{array}{l}\text { beta-subunits of the Snf1 } \\
\text { kinase complex }\end{array}$ & PRKAB1, PRKAB2 & & + & & \\
\hline GUA1 & YMR217W & 6323873 & GMP synthase & GMPS & + & + & + & \\
\hline HBT1 & YDL223C & 6319978 & Shmoo tip protein & - & & & & \\
\hline HRK1 & YOR267C & 6324841 & $\begin{array}{l}\text { Serine/threonine protein } \\
\text { kinase }\end{array}$ & HUNK, PRKAA2 & + & & & \\
\hline ILV1 & YER086W & 6320930 & $\begin{array}{c}\text { Mitochondrial threonine } \\
\text { dehydratase }\end{array}$ & 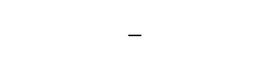 & & & & \\
\hline IST2 & YBR086C & 27808701 & $\begin{array}{l}\text { Increased sodium tolerance } \\
\text { protein }\end{array}$ & $\begin{array}{l}\text { ANO1, ANO2, ANO3, } \\
\text { ANO4, ANO5, ANO6, } \\
\text { ANO7 }\end{array}$ & & & & \\
\hline MOT3 & YMR070W & 6323715 & $\begin{array}{l}\text { Transcriptional } \\
\text { activator/repressor }\end{array}$ & SMARCA2, SMARCA4 & + & & & + \\
\hline NMA1 & YLR328W & 6323360 & $\begin{array}{l}\text { Nicotinic acid } \\
\text { mononucleotide } \\
\text { adenylyltransferase }\end{array}$ & $\begin{array}{l}\text { NMNAT1, NMNAT2, } \\
\text { NMNAT3 }\end{array}$ & + & + & & \\
\hline NMA2 & YGR010W & 6321447 & $\begin{array}{l}\text { Nicotinic acid } \\
\text { mononucleotide } \\
\text { adenylyltransferase }\end{array}$ & $\begin{array}{l}\text { NMNAT1, NMNAT2, } \\
\text { NMNAT3 }\end{array}$ & + & + & & \\
\hline NOG2 & YNR053C & 6324381 & $\begin{array}{l}\text { Nucleolar GTP-binding } \\
\text { protein }\end{array}$ & GNL2 & + & & & \\
\hline OLE1 & YGL055W & 398364717 & Acyl-CoA desaturase & SCD, SCD5 & + & + & & \\
\hline OPY1 & YBR129C & 6319605 & $\begin{array}{l}\text { Protein of unknown } \\
\text { function }\end{array}$ & PLEK, PLEK2 & & & & \\
\hline PAL2 & YHR097C & 6321889 & $\begin{array}{l}\mathrm{pH} \text {-response regulator } \\
\text { protein }\end{array}$ & - & & & & \\
\hline PBP1 & YGR178C & 398366039 & $\begin{array}{l}\text { PAB1-binding protein } \\
\text { ATPase of the 19S }\end{array}$ & ATXN2, ATXN2L & + & & + & \\
\hline RPT1 & YKL145W & 6322704 & $\begin{array}{l}\text { regulatory particle of the } \\
26 \mathrm{~S} \text { proteasome }\end{array}$ & PSMC2 & + & & & \\
\hline RTK1 & YDL025C & 6320179 & $\begin{array}{c}\text { Probable serine/threonine } \\
\text { protein kinase }\end{array}$ & HUNK, PRKAA2 & + & & + & \\
\hline RVB2 & YPL235W & 6325021 & RuvB-like protein & $\begin{array}{c}\text { RUVBL2 } \\
\text { HUNK, MELK, }\end{array}$ & + & & & \\
\hline SNF1 & YDR477W & 398366631 & $\begin{array}{l}\text { AMP-activated } \mathrm{S} / \mathrm{T} \text { protein } \\
\text { kinase }\end{array}$ & $\begin{array}{l}\text { PRKAA1, PRKAA2, } \\
\text { STK40, TRIB1, TRIB2, } \\
\text { TRIB3 }\end{array}$ & + & + & + & \\
\hline SOF1 & YLL011W & 6323018 & $\begin{array}{l}\text { Protein required for } \\
\text { biogenesis of } 40 S \text { (small) } \\
\text { ribosomal subunit }\end{array}$ & DCAF13 & + & & & \\
\hline SRO9 & YCL037C & 37362625 & $\begin{array}{l}\text { Cytoplasmic RNA-binding } \\
\text { protein }\end{array}$ & LARP1, LARP4B & + & & + & \\
\hline SRV2 & YNL138W & 6324191 & $\begin{array}{c}\text { CAP (cyclase-associated } \\
\text { protein) }\end{array}$ & - & & & & \\
\hline TUB1 & YML085C & 6323554 & Tubulin alpha-1 chain & TUBA8 & + & & & \\
\hline
\end{tabular}


Table 3. Cont.

\begin{tabular}{|c|c|c|c|c|c|c|c|c|}
\hline $\begin{array}{l}\text { Common } \\
\text { Name }\end{array}$ & $\begin{array}{l}\text { ORF } \\
\text { Name }\end{array}$ & $\begin{array}{l}\text { Protein ID } \\
\text { (gi\#) }\end{array}$ & Description & Human Orthologues & $\mathrm{HCB}^{1}$ & Mtb ${ }^{2}$ & $\mathrm{Ubl}^{3}$ & Acet ${ }^{4}$ \\
\hline TUB2 & YFL037W & 14318481 & $\begin{array}{l}\text { Beta-tubulin, associates } \\
\text { with alpha-tubulin }\end{array}$ & $\begin{array}{c}\text { TUBB, TUBB1, TUBB2A, } \\
\text { TUBB2B, TUBB3, } \\
\text { TUBB4A, TUBB4B, } \\
\text { TUBB6, TUBE1 }\end{array}$ & + & & & \\
\hline UGP1 & YKL035W & 398364619 & $\begin{array}{l}\text { UTP-glucose-1-phosphate } \\
\text { uridylyltransferase } \\
\text { Flap-structured }\end{array}$ & UAP1, UGP2 & & + & & + \\
\hline VTS1 & YOR359W & 398366369 & $\begin{array}{l}\text { DNA-binding and } \\
\text { RNA-binding protein }\end{array}$ & SAMD4A & + & & & \\
\hline WHI2 & YOR043W & 6324617 & Growth regulation protein & - & & & & \\
\hline YBR238C & YBR238C & 6319715 & $\begin{array}{l}\text { Mitochondrial membrane } \\
\text { protein }\end{array}$ & - & + & & & \\
\hline YCK2 & YNL154C & 6324175 & $\begin{array}{l}\text { Palmitoylated plasma } \\
\text { membrane-bound casein } \\
\text { kinase I (CK1) isoform }\end{array}$ & CSNK1G2 & + & & + & + \\
\hline YGR237C & YGR237C & 6321676 & Uncharacterized protein & - & & & & \\
\hline
\end{tabular}

${ }^{1}$ Heterocyclic compound binding; ${ }^{2}$ metabolism; ${ }^{3}$ Ubl conjugation; ${ }^{4}$ acetylation.

\subsection{Mot3 is Essential for Heme Activation of Gis1 Transcriptional Activity}

Mot3 is a known transcriptional regulator involved in the regulation of a subset of hypoxic genes $[57,58,82,83]$. Thus, we further ascertained its functional importance in heme regulation of Gis1 activity. Note that in wild type cells, which express both Gis1 and Mot3, Gis1 transcriptional activity was stimulated in heme-sufficient cells (high ALA, Figure 7A) relative to heme-deficient cells (low ALA). When the MOT3 gene was deleted ( $\triangle$ mot3, Figure 7A), Gis1 transcriptional activity in heme-deficient cells remained at a similar level as in wild type cells. However, Gis1 activity in heme-sufficient cells was no longer higher than in heme-deficient cells in $\Delta$ mot3 cells. Figure $7 \mathrm{~A}$ shows that deletion of MOT3 did not affect Gis1 activity in heme-deficient cells, but abolished heme activation of Gis1 activity in heme-sufficient cells. Next, we examined the effect of MOT3 deletion on the transcriptional activities of various Gis1 deletion mutants in heme-sufficient cells (cells grown in the presence of high levels of ALA, Figure 7B). We found that deletion of MOT3 also strongly reduced the activity of Gis1 deletion proteins lacking JmjN and/or JmjC domains (Figure 7B). This result was consistent with previous studies showing that the JmjN/C domain does not affect Gis1 transcriptional activity [36]. Together, our results showed that Mot3 specifically interacts with Gis1 and is essential for heme activation of Gis1 transcriptional activity.
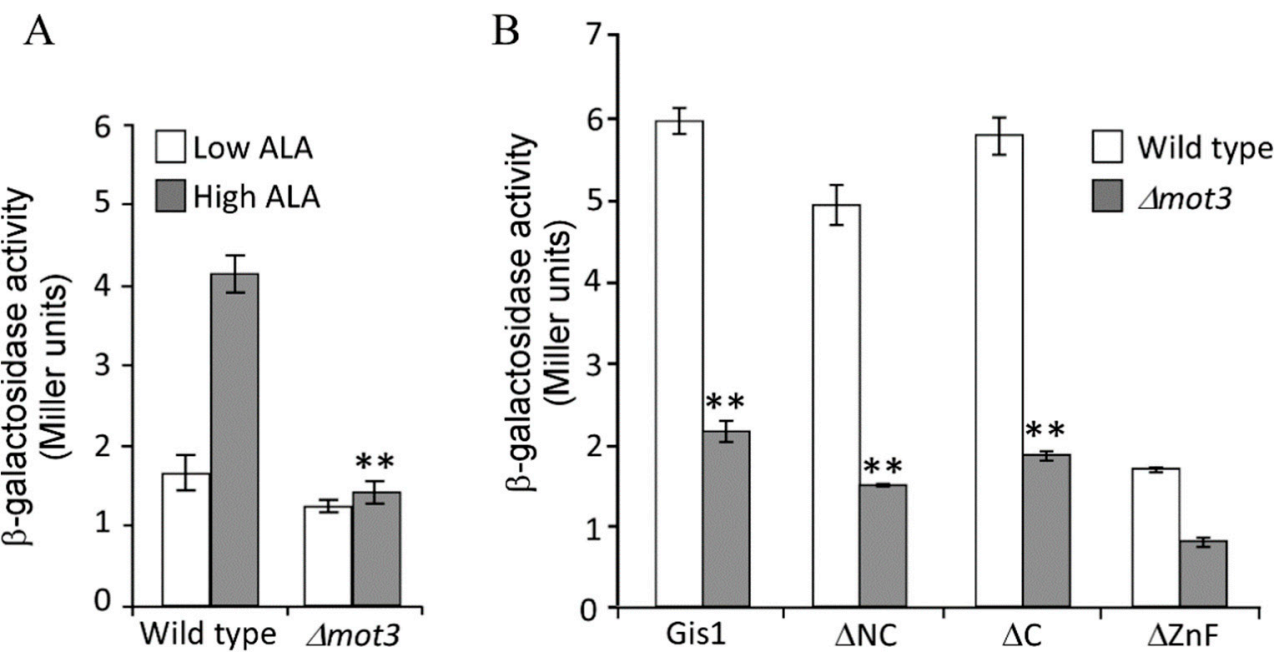

Figure 7. Mot3 is required for heme activation of Gis1 transcriptional activity in vivo. (A) Deletion of 
the MOT3 gene reduces Gis1 transcriptional activity in heme-sufficient cells. Wild type $\Delta$ hem1 (WT) or $\Delta$ mot3 $\Delta$ hem 1 ( $\Delta$ mot3) cells bearing the PDS-lacZ reporter and expressing Gis1 were grown at a low $(2.5 \mu \mathrm{g} / \mathrm{mL})$ or high levels $(250 \mu \mathrm{g} / \mathrm{mL})$ of ALA. $\beta$-galactosidase activities (mean+SD) were measured from at least three independent cultures. For statistical analysis, the activities in wild type cells were compared to those in $\Delta$ mot3 cells at the same heme levels with a Welch 2-sample t-test. ${ }^{* *} p$ value, 0.0001 . (B) Deletion of the Gis1 JmjN/C domain does not abolish the requirement of Mot3 for heme activation. $\beta$-galactosidase activities (mean $+\mathrm{SD}$ ) were measured from at least three independent cultures of yeast wild type (HEM1 deletion) or $\triangle m o t 3$ cells bearing the PDS-lacZ reporter and expressing Gis1 full-length or deletion proteins grown at high levels $(250 \mu \mathrm{g} / \mathrm{mL})$ of ALA. For statistical analysis, the activities in wild type cells were compared to those in $\Delta$ mot3 cells using a Welch 2 -sample t-test. ${ }^{* *} p$ value, 0.0001 .

\section{Discussion}

The JmjC domain-containing proteins are highly conserved from yeast to humans, with 32 found in humans [8,11]. These proteins are dioxygenases and often possess histone demethylase activity [2-4]. The human JMJB2/KDM4 subfamily of histone demethylases has five functional members, namely, KDM4A-4E [8,11]. KDM4A, B, and C are broadly expressed in normal human tissues, while KDM4D and $\mathrm{E}$ (containing only JmjN+JmjC domain) are predominantly expressed in the testes in humans $[13,84]$. The functional domains of KDM4 proteins share high homology with Gis1 domains (Figure 1). KDM4 proteins, like Gis1, are responsive to nutritional and metabolic signals, in part due to their requirement for $\alpha$-ketoglutarate (AKG), $\mathrm{Fe}^{2+}$, and $\mathrm{O}_{2}$ for activity [17-21]. KDM4 proteins play important roles in diverse biological processes, and their altered expression or function has been implicated in multiple cancers, cardiovascular diseases, and mental retardation [8,15,85-88].

Heme acts as a prosthetic group or cofactor in proteins and enzymes required for oxygen utilization and metabolism, such as globins and cytochromes [44-47]. Heme serves as a signaling molecule regulating diverse processes ranging from gene transcription to circadian rhythm [48-50]. Heme directly binds to and modulates the activities of certain cellular proteins, such as the yeast heme-regulatory protein Hap1 [51,52] and the mammalian nuclear receptor Rev-erb $\alpha$ [49,53]. In humans, heme deficiency causes serious diseases such as anemia and porphyria [89]. Conversely, high heme intake is associated with increased risk of cancer, type 2 diabetes, and coronary heart disease [90]. In yeast and mammals, intracellular heme levels are influenced by multiple factors including carbon sources, oxygen levels, heme availability, and circadian rhythm [77,89,91,92].

In this work, our data provide a direct link between KDM4 activities and heme, enabling the coordination of the regulation of histone demethylation, chromatin structure, and gene regulation with changes in heme levels and cellular stimuli and factors influencing heme levels. This link also provides an additional level of regulation of KDM4 activities by metabolic status relating to oxidative metabolism. The metabolic status influences KDM4 demethylase activity at two levels. The first level involves the requirement of $\alpha$-ketoglutarate, $\mathrm{Fe}^{2+}$, and $\mathrm{O}_{2}$ for demethylase activity. $\alpha$-ketoglutarate is a metabolite of the TCA cycle, which is a key part of oxidative metabolism. Interestingly, $\alpha$-ketoglutarate is also a source of succinyl-CoA for heme synthesis [93]. $\mathrm{Fe}^{2+}$ and $\mathrm{O}_{2}$ are important nutrients and metabolic substrates which are required for heme synthesis. Heme synthesis also requires succinyl CoA, which is a metabolite of the TCA cycle. The second level of regulation is directly mediated by heme regulation of KDM4 histone demethylase activity. These two levels of regulation provide a tight regulatory scheme to coordinate KDM4 histone demethylase activity with the status of oxidative metabolism, oxygen, iron, and heme. Interestingly, although the JmjN/C domains of Gis1 and KDM4A/B/C are highly homologous (Figure 1) and can all bind to heme (Figures 2 and 3), only those of KDM4A and C can mediate heme regulation of histone demethylase activity (Figure 4). Further structure-function analyses of these domains may shed light on the molecular codes underpinning heme regulation of histone demethylase activity.

The KDM4 proteins, particularly KDM4A/B/C and Gis1, contain multiple functional domains that are known to be versatile in their interactions with other macromolecules. A total of 195 protein-protein interactions (physical and genetic) were identified for Gis1, with 149 unique interactions 
(see https://thebiogrid.org/32151/summary/saccharomyces-cerevisiae/gis1.html). These interactions can be mediated by the JmjN/C domain, the C-terminal $\mathrm{ZnF}$ domain, or any other domains (Figure 1). PHD and Tudor domains of $\mathrm{KDM} 4 \mathrm{~A} / \mathrm{B} / \mathrm{C}$ are histone reader domains that interact with post-translationally modified histones, as well as other proteins and DNA [40-43]. These domains, like the JmjN/C domain, have high potential to interact with many protein partners. Indeed, most of the Gis1-interacting proteins have human orthologues (see Tables 1-3). These human orthologues are likely to interact with $\mathrm{KDM} 4 \mathrm{~A} / \mathrm{B} / \mathrm{C}$ proteins and influence diverse processes and pathways.

Interestingly, GO analysis of the Gis1-interacting proteins identified several prominent classes (Table 1: hypoxic conditions; Table 2: heme-sufficient conditions; Table 3: hypoxic and heme-sufficient conditions). The first class includes those proteins that bind to heterocyclic compounds, including 25 from hypoxic conditions, 19 from heme-sufficient conditions, and 24 from hypoxic and heme-sufficient conditions. Heterocyclic compounds are effective inhibitors of KDM4 activity [94,95], thus, it is fitting that many Gis1-interacting proteins can interact with heterocyclic compounds. The second class include those involved in metabolism, including nine from hypoxic conditions, 13 from heme-sufficient conditions, and 10 from hypoxic and heme-sufficient conditions. Gis1 and KDM4 proteins require the metabolites $\alpha$-ketoglutarate, $\mathrm{Fe}^{2+}$, and $\mathrm{O}_{2}$ for activity. Furthermore, heme levels are directly linked to metabolic and nutritional conditions. Gis1 and KDM4 can sense heme levels and metabolic changes. The interactions of proteins involved in metabolism with Gis1 and perhaps KDM4 proteins are likely to facilitate the response of Gis1 and KDM4 proteins to changes in metabolic and nutritional conditions. The third class are those that can be conjugated by ubiquitin-like ( $\mathrm{Ubl})$ proteins, including seven from hypoxic conditions, four from heme-sufficient conditions, and nine from hypoxic and heme-sufficient conditions. Previous studies showed that ubiquitination and proteasomes are involved in controlling the levels of Gis1 and KDM4 proteins [60,96,97]. The association of Gis1 and likely KDM4 proteins with ubiquitination machinery probably allows them to associate with other ubiquitin-modified proteins. The fourth class include those that are acetylated, including twelve from hypoxic conditions, seven from heme-sufficient conditions, and three from hypoxic and heme-sufficient conditions. Methylation and acetylation are two important histone modifications that strongly influence chromatin structure and gene regulation. Previous studies indicated that crosstalk existed between acetylation and demethylation [98,99]. Our results in this work, which showed that many Gis1-interacting partners are acetylated, suggested that many potential crosstalk pathways exist between demethylation and acetylation.

It is also worth noting that C-terminal regions of KDM4 proteins, like the $\mathrm{ZnF}$ domain of Gis1, can promote heme regulation of unrelated transcriptional activators (Figure 5). This finding, alongside the data showing the effect of heme on histone demethylase activity of KDM4A and C, demonstrates that heme is a global regulator of KDM4 proteins. Furthermore, over 100 Gis1-interacting partners with diverse cellular functions exist, and these proteins often have human orthologues (Tables 1-3). Thus, the Gis1-KDM4 regulatory network appears to consist of many proteins and is well organized to respond to changes in metabolic and nutritional conditions. It is highly likely that human KDM4 proteins can interact with many proteins to influence diverse cellular pathways and processes.

Supplementary Materials: The following are available online at http://www.mdpi.com/2073-4409/9/3/773/s1, Figure S1: Absorption spectra of heme bound to the JmjN/C domain of Gis1 or KDM4A/B/C in the presence of increasing concentrations of imidazole; Figure S2: Proteins pulled down with His6-tagged Gis1 in the presence of yeast extracts prepared from cells grown under normoxic conditions (A), hypoxic conditions (B), intermediate amounts of heme precursor ALA (C), or high amounts of ALA (D).

Author Contributions: Conceptualization, L.Z., P.C.K., and T.W.; methodology, L.Z., P.C.K., and T.W.; data acquisition, P.C.K., T.W., and N.S.; writing—original draft preparation, L.Z., P.C.K., and T.W.; writing-review and editing, L.Z., P.C.K., T.W., and N.S.; supervision, L.Z.; funding acquisition, L.Z. All authors have read and agreed to the published version of the manuscript.

Funding: This work was supported by funds from the National Institute of General Medical Sciences [R15GM107717 to L.Z.]. 
Acknowledgments: We are very grateful to Drs. Claudio De Virgilio (University of Fribourg, Switzerland), George M. Carman (Rutgers University, New Jersey), Rolf Sternglanz (Stony Brook University, New York), and Nianshu Zhang (University of Cambridge, UK) for their generous support of Gis1 expression and reporter plasmids. We are indebted to Drs. Lei Wang and Elisabeth D. Martinez (UT Southwestern Medical Center, Texas) for kindly providing us with information and advice about demethylase assays. We thank Dr. Zhenyu Xuan (UT Dallas, Texas) for assistance in bioinformatics analysis.

Conflicts of Interest: The authors declare that they have no conflict of interest.

\section{References}

1. Shi, Y. Histone lysine demethylases: Emerging roles in development, physiology and disease. Nat. Rev. Genet. 2007, 8, 829-833. [CrossRef] [PubMed]

2. Klose, R.J.; Zhang, Y. Regulation of histone methylation by demethylimination and demethylation. Nat. Rev. Mol. Cell Biol. 2007, 8, 307-318. [CrossRef]

3. Chen, Z.; Zang, J.; Whetstine, J.; Hong, X.; Davrazou, F.; Kutateladze, T.G.; Simpson, M.; Mao, Q.; Pan, C.H.; Dai, S.; et al. Structural insights into histone demethylation by JMJD2 family members. Cell 2006, 125, 691-702. [CrossRef] [PubMed]

4. Johansson, C.; Tumber, A.; Che, K.; Cain, P.; Nowak, R.; Gileadi, C.; Oppermann, U. The roles of Jumonji-type oxygenases in human disease. Epigenomics 2014, 6, 89-120. [CrossRef] [PubMed]

5. Williams, S.T.; Walport, L.J.; Hopkinson, R.J.; Madden, S.K.; Chowdhury, R.; Schofield, C.J.; Kawamura, A. Studies on the catalytic domains of multiple JmjC oxygenases using peptide substrates. Epigenetics 2014, 9, 1596-1603. [CrossRef] [PubMed]

6. Trojer, P.; Zhang, J.; Yonezawa, M.; Schmidt, A.; Zheng, H.; Jenuwein, T.; Reinberg, D. Dynamic Histone H1 Isotype 4 Methylation and Demethylation by Histone Lysine Methyltransferase G9a/KMT1C and the Jumonji Domain-containing JMJD2/KDM4 Proteins. J. Biol. Chem. 2009, 284, 8395-8405. [CrossRef]

7. Hillringhaus, L.; Yue, W.W.; Rose, N.R.; Ng, S.S.; Gileadi, C.; Loenarz, C.; Bello, S.H.; Bray, J.E.; Schofield, C.J.; Oppermann, U. Structural and evolutionary basis for the dual substrate selectivity of human KDM4 histone demethylase family. J. Biol. Chem. 2011, 286, 41616-41625. [CrossRef]

8. Labbe, R.M.; Holowatyj, A.; Yang, Z.Q. Histone lysine demethylase (KDM) subfamily 4: Structures, functions and therapeutic potential. Am. J. Transl. Res. 2014, 6, 1-15.

9. Cloos, P.A.; Christensen, J.; Agger, K.; Maiolica, A.; Rappsilber, J.; Antal, T.; Hansen, K.H.; Helin, K. The putative oncogene GASC1 demethylates tri- and dimethylated lysine 9 on histone H3. Nature 2006, 442, 307-311. [CrossRef]

10. Wissmann, M.; Yin, N.; Muller, J.M.; Greschik, H.; Fodor, B.D.; Jenuwein, T.; Vogler, C.; Schneider, R.; Gunther, T.; Buettner, R.; et al. Cooperative demethylation by JMJD2C and LSD1 promotes androgen receptor-dependent gene expression. Nat. Cell Biol. 2007, 9, 347-353. [CrossRef]

11. Klose, R.J.; Kallin, E.M.; Zhang, Y. JmjC-domain-containing proteins and histone demethylation. Nat. Rev. Genet. 2006, 7, 715-727. [CrossRef]

12. Whetstine, J.R.; Nottke, A.; Lan, F.; Huarte, M.; Smolikov, S.; Chen, Z.; Spooner, E.; Li, E.; Zhang, G.; Colaiacovo, M.; et al. Reversal of histone lysine trimethylation by the JMJD2 family of histone demethylases. Cell 2006, 125, 467-481. [CrossRef] [PubMed]

13. Shin, S.; Janknecht, R. Diversity within the JMJD2 histone demethylase family. Biochem. Biophys. Res. Commun. 2007, 353, 973-977. [CrossRef] [PubMed]

14. Agger, K.; Nishimura, K.; Miyagi, S.; Messling, J.E.; Rasmussen, K.D.; Helin, K. The KDM4/JMJD2 histone demethylases are required for hematopoietic stem cell maintenance. Blood 2019, 134, 1154-1158. [CrossRef] [PubMed]

15. Filiu-Braga, L.D.C.; Serejo, T.R.T.; Lucena-Araujo, A.R.; Neves, F.A.R.; de Carvalho, J.L.; Rego, E.M.; Saldanha-Araujo, F. Unraveling KDM4 histone demethylase expression and its association with adverse cytogenetic findings in chronic lymphocytic leukemia. Med. Oncol 2018, 36, 3. [CrossRef]

16. Kang, M.K.; Mehrazarin, S.; Park, N.H.; Wang, C.Y. Epigenetic gene regulation by histone demethylases: Emerging role in oncogenesis and inflammation. Oral Dis 2017, 23, 709-720. [CrossRef]

17. Teperino, R.; Schoonjans, K.; Auwerx, J. Histone methyl transferases and demethylases; can they link metabolism and transcription? Cell Metab. 2010, 12, 321-327. [CrossRef] 
18. Kaelin, W.G., Jr. Cancer and altered metabolism: Potential importance of hypoxia-inducible factor and 2-oxoglutarate-dependent dioxygenases. Cold Spring Harb. Symp. Quant. Biol. 2011, 76, 335-345. [CrossRef]

19. Gut, P.; Verdin, E. The nexus of chromatin regulation and intermediary metabolism. Nature 2013, 502, 489-498. [CrossRef]

20. Carbonneau, M.; Gagné, L.M.; Lalonde, M.E.; Germain, M.A.; Motorina, A.; Guiot, M.C.; Secco, B.; Vincent, E.E.; Tumber, A.; Hulea, L.; et al. The oncometabolite 2-hydroxyglutarate activates the mTOR signalling pathway. Nat. Commun. 2016, 7, 12700. [CrossRef]

21. Filipp, F.V. Crosstalk between epigenetics and metabolism-Yin and Yang of histone demethylases and methyltransferases in cancer. Brief. Funct. Genomics 2017, 16, 320-325. [CrossRef] [PubMed]

22. Salminen, A.; Kauppinen, A.; Hiltunen, M.; Kaarniranta, K. Krebs cycle intermediates regulate DNA and histone methylation: Epigenetic impact on the aging process. Ageing Res. Rev. 2014, 16, 45-65. [CrossRef] [PubMed]

23. Lal, S.; Comer, J.M.; Konduri, P.C.; Shah, A.; Wang, T.; Lewis, A.; Shoffner, G.; Guo, F.; Zhang, L. Heme promotes transcriptional and demethylase activities of Gis1, a member of the histone demethylase JMJD2/KDM4 family. Nucleic Acids Res. 2018, 46, 215-228. [CrossRef]

24. Kwon, D.W.; Ahn, S.H. Role of yeast JmjC-domain containing histone demethylases in actively transcribed regions. Biochem. Biophys. Res. Commun. 2011, 410, 614-619. [CrossRef] [PubMed]

25. Sein, H.; Varv, S.; Kristjuhan, A. Distribution and maintenance of histone H3 lysine 36 trimethylation in transcribed locus. PLoS ONE 2015, 10, e0120200. [CrossRef]

26. Tu, S.; Bulloch, E.M.; Yang, L.; Ren, C.; Huang, W.C.; Hsu, P.H.; Chen, C.H.; Liao, C.L.; Yu, H.M.; Lo, W.S.; et al. Identification of histone demethylases in Saccharomyces cerevisiae. J. Biol. Chem. 2007, 282, 14262-14271. [CrossRef]

27. Cameroni, E.; Hulo, N.; Roosen, J.; Winderickx, J.; De Virgilio, C. The novel yeast PAS kinase Rim 15 orchestrates G0-associated antioxidant defense mechanisms. Cell Cycle 2004, 3, 462-468. [CrossRef]

28. Roosen, J.; Engelen, K.; Marchal, K.; Mathys, J.; Griffioen, G.; Cameroni, E.; Thevelein, J.M.; De Virgilio, C.; De Moor, B.; Winderickx, J. PKA and Sch9 control a molecular switch important for the proper adaptation to nutrient availability. Mol. Microbiol. 2005, 55, 862-880. [CrossRef]

29. Cheng, C.; Fabrizio, P.; Ge, H.; Longo, V.D.; Li, L.M. Inference of transcription modification in long-live yeast strains from their expression profiles. BMC Genomics 2007, 8, 219. [CrossRef]

30. Zhang, N.; Wu, J.; Oliver, S.G. Gis1 is required for transcriptional reprogramming of carbon metabolism and the stress response during transition into stationary phase in yeast. Microbiology 2009, 155, 1690-1698. [CrossRef]

31. Wei, M.; Fabrizio, P.; Madia, F.; Hu, J.; Ge, H.; Li, L.M.; Longo, V.D. Tor1/Sch9-regulated carbon source substitution is as effective as calorie restriction in life span extension. PLoS Genet. 2009, 5, e1000467. [CrossRef] [PubMed]

32. Orzechowski Westholm, J.; Tronnersjo, S.; Nordberg, N.; Olsson, I.; Komorowski, J.; Ronne, H. Gis1 and Rph1 regulate glycerol and acetate metabolism in glucose depleted yeast cells. PLoS ONE 2012, 7, e31577. [CrossRef] [PubMed]

33. Boorstein, W.R.; Craig, E.A. Regulation of a yeast HSP70 gene by a cAMP responsive transcriptional control element. EMBO J. 1990, 9, 2543-2553. [CrossRef] [PubMed]

34. Pedruzzi, I.; Burckert, N.; Egger, P.; De Virgilio, C. Saccharomyces cerevisiae Ras/cAMP pathway controls post-diauxic shift element-dependent transcription through the zinc finger protein Gis1. EMBO J. 2000, 19, 2569-2579. [CrossRef]

35. Jang, Y.K.; Wang, L.; Sancar, G.B. RPH1 and GIS1 are damage-responsive repressors of PHR1. Mol. Cell Biol. 1999, 19, 7630-7638. [CrossRef]

36. Yu, Y.; Neiman, A.M.; Sternglanz, R. The JmjC domain of Gis1 is dispensable for transcriptional activation. FEMS Yeast Res. 2010, 10, 793-801. [CrossRef]

37. Quan, Z.; Oliver, S.G.; Zhang, N. JmjN interacts with JmjC to ensure selective proteolysis of Gis1 by the proteasome. Microbiology 2011, 157, 2694-2701. [CrossRef]

38. Pascual, J.; Martinez-Yamout, M.; Dyson, H.J.; Wright, P.E. Structure of the PHD zinc finger from human Williams-Beuren syndrome transcription factor. J. Mol. Biol. 2000, 304, 723-729. [CrossRef]

39. Lu, R.; Wang, G.G. Tudor: A versatile family of histone methylation 'readers'. Trends Biochem. Sci. 2013, 38, 546-555. [CrossRef] 
40. Musselman, C.A.; Kutateladze, T.G. PHD fingers: Epigenetic effectors and potential drug targets. Mol. Interv. 2009, 9, 314-323. [CrossRef]

41. Musselman, C.A.; Kutateladze, T.G. Handpicking epigenetic marks with PHD fingers. Nucleic Acids Res. 2011, 39, 9061-9071. [CrossRef] [PubMed]

42. Sanchez, R.; Zhou, M.M. The PHD finger: A versatile epigenome reader. Trends Biochem. Sci. 2011, 36, 364-372. [CrossRef] [PubMed]

43. Adams-Cioaba, M.A.; Min, J. Structure and function of histone methylation binding proteins. Biochem. Cell Biol. 2009, 87, 93-105. [CrossRef] [PubMed]

44. Bock, K.W.; De Matteis, F.; Aldridge, W.N. Heme and Hemoproteins; Springer: Berlin/Heidelberg, Germany, 1978; pp. 49-80.

45. Ponka, P. Cell biology of heme. Am. J. Med. Sci. 1999, 318, 241-256. [CrossRef]

46. Ortiz de Montellano, P.R. Hemes in Biology. In Wiley Encyclopedia of Chemical Biology; John Wiley \& Sons, Ltd.: Chichester, West Sussex, UK; Hoboken, NJ, USA, 2009; pp. 240-249.

47. Padmanaban, G.; Venkateswar, V.; Rangarajan, P.N. Haem as a multifunctional regulator. Trends Biochem. Sci. 1989, 14, 492-496. [CrossRef]

48. Sassa, S. Novel effects of heme and heme-related compounds in biological systems. Current Med. Chem. 1996, 3, 273-290.

49. Yin, L.; Wu, N.; Curtin, J.C.; Qatanani, M.; Szwergold, N.R.; Reid, R.A.; Waitt, G.M.; Parks, D.J.; Pearce, K.H.; Wisely, G.B.; et al. Rev-erbalpha, a heme sensor that coordinates metabolic and circadian pathways. Science 2007, 318, 1786-1789. [CrossRef]

50. Weitz, S.H.; Gong, M.; Barr, I.; Weiss, S.; Guo, F. Processing of microRNA primary transcripts requires heme in mammalian cells. Proc. Natl. Acad. Sci. USA 2014, 111, 1861-1866. [CrossRef]

51. Zhang, L.; Guarente, L. Heme binds to a short sequence that serves a regulatory function in diverse proteins. EMBO J. 1995, 14, 313-320. [CrossRef]

52. Zhang, L.; Hach, A. Molecular mechanism of heme signaling in yeast: The transcriptional activator Hap1 serves as the key mediator. Cell Mol. Life Sci. 1999, 56, 415-426. [CrossRef]

53. Raghuram, S.; Stayrook, K.R.; Huang, P.; Rogers, P.M.; Nosie, A.K.; McClure, D.B.; Burris, L.L.; Khorasanizadeh, S.; Burris, T.P.; Rastinejad, F. Identification of heme as the ligand for the orphan nuclear receptors REV-ERBalpha and REV-ERBbeta. Nat. Struct. Mol. Biol. 2007, 14, 1207-1213. [CrossRef] [PubMed]

54. Chiabrando, D.; Fiorito, V.; Petrillo, S.; Tolosano, E. Unraveling the Role of Heme in Neurodegeneration. Front. Neurosci. 2018, 12, 712. [CrossRef] [PubMed]

55. Sohoni, S.; Ghosh, P.; Wang, T.; Kalainayakan, S.P.; Vidal, C.; Dey, S.; Konduri, P.C.; Zhang, L. Elevated Heme Synthesis and Uptake Underpin Intensified Oxidative Metabolism and Tumorigenic Functions in Non-Small Cell Lung Cancer Cells. Cancer Res. 2019, 79, 2511-2525. [CrossRef] [PubMed]

56. Galmozzi, A.; Kok, B.P.; Kim, A.S.; Montenegro-Burke, J.R.; Lee, J.Y.; Spreafico, R.; Mosure, S.; Albert, V.; Cintron-Colon, R.; Godio, C.; et al. PGRMC2 is an intracellular haem chaperone critical for adipocyte function. Nature 2019, 576, 138-142. [CrossRef] [PubMed]

57. Grishin, A.V.; Rothenberg, M.; Downs, M.A.; Blumer, K.J. Mot3, a Zn finger transcription factor that modulates gene expression and attenuates mating pheromone signaling in Saccharomyces cerevisiae. Genetics 1998, 149, 879-892. [PubMed]

58. Martinez-Montanes, F.; Rienzo, A.; Poveda-Huertes, D.; Pascual-Ahuir, A.; Proft, M. Activator and repressor functions of the Mot3 transcription factor in the osmostress response of Saccharomyces cerevisiae. Eukaryot. Cell 2013, 12, 636-647. [CrossRef] [PubMed]

59. Oshiro, J.; Han, G.S.; Iwanyshyn, W.M.; Conover, K.; Carman, G.M. Regulation of the yeast DPP1-encoded diacylglycerol pyrophosphate phosphatase by transcription factor Gis1p. J. Biol. Chem. 2003, 278, 31495-31503. [CrossRef]

60. Zhang, N.; Oliver, S.G. The transcription activity of Gis1 is negatively modulated by proteasome-mediated limited proteolysis. J. Biol. Chem. 2010, 285, 6465-6476. [CrossRef]

61. Turcotte, B.; Guarente, L. HAP1 positive control mutants specific for one of two binding sites. Genes Dev. 1992, 6, 2001-2009. [CrossRef]

62. Zhang, L.; Guarente, L. The C6 zinc cluster dictates asymmetric binding by HAP1. EMBO J. 1996, 15, 4676-4681. [CrossRef] 
63. Hon, T.; Lee, H.C.; Zhang, L. The actions of Hsp90 and Hsp70 molecular chaperones in heme signaling in eukaryotes. In Recent Research Developments in Molecular and Cellular Biology; Fagan, J., Shimizu, N., Davidson, J.N., Eds.; Research Signpost: Trivandrum, India, 2003; pp. 11-21.

64. Kundaje, A.; Xin, X.; Lan, C.; Lianoglou, S.; Zhou, M.; Zhang, L.; Leslie, C. A predictive model of the oxygen and heme regulatory network in yeast. PLoS Comput. Biol. 2008, 4, e1000224. [CrossRef] [PubMed]

65. Hon, T.; Hach, A.; Lee, H.C.; Chen, T.; Zhang, L. Functional analysis of heme regulatory elements of the transcriptional activator Hap1. Biochem. Biophys Res. Commun. 2000, 273, 584-591. [CrossRef] [PubMed]

66. Hon, T.; Hach, A.; Tamalis, D.; Zhu, Y.; Zhang, L. The yeast heme-responsive transcriptional activator Hap1 is a preexisting dimer in the absence of heme. J. Biol. Chem. 1999, 274, 22770-22774. [CrossRef] [PubMed]

67. Zhang, L.; Guarente, L. HAP1 is nuclear but is bound to a cellular factor in the absence of heme. J. Biol. Chem. 1994, 269, 14643-14647. [PubMed]

68. Zhang, L.; Hach, A.; Wang, C. Molecular mechanism governing heme signaling in yeast: A higher-order complex mediates heme regulation of the transcriptional activator HAP1. Mol. Cell Biol. 1998, 18, 3819-3828. [CrossRef] [PubMed]

69. Ghosh Dastidar, R.; Hooda, J.; Shah, A.; Cao, T.M.; Henke, R.M.; Zhang, L. The nuclear localization of SWI/SNF proteins is subjected to oxygen regulation. Cell Biosci. 2012, 2, 30. [CrossRef]

70. Mellacheruvu, D.; Wright, Z.; Couzens, A.L.; Lambert, J.P.; St-Denis, N.A.; Li, T.; Miteva, Y.V.; Hauri, S.; Sardiu, M.E.; Low, T.Y.; et al. The CRAPome: A contaminant repository for affinity purification-mass spectrometry data. Nat. Methods 2013, 10, 730-736. [CrossRef]

71. Hon, T.; Lee, H.C.; Hach, A.; Johnson, J.L.; Craig, E.A.; Erdjument-Bromage, H.; Tempst, P.; Zhang, L. The Hsp70-Ydj1 Molecular Chaperone Represses the Activity of the Transcriptional Activator Hap1 in the Absence of Heme. Mol. Cell Biol. 2001, 21, 7923-7932. [CrossRef]

72. Gerace, E.; Moazed, D. Affinity Purification of Protein Complexes Using TAP Tags. Methods Enzymol. 2015, $559,37-52$.

73. Ishimori, K.; Watanabe, Y. Unique Heme Environmental Structures in Heme-regulated Proteins Using Heme as the Signaling Molecule. Chem. Lett. 2014, 43, 1680-1689. [CrossRef]

74. Yao, X.; Balamurugan, P.; Arvey, A.; Leslie, C.; Zhang, L. Heme controls the regulation of protein tyrosine kinases Jak2 and Src. Biochem. Biophys Res. Commun. 2010, 403, 30-35. [CrossRef] [PubMed]

75. Liew, C.K.; Simpson, R.J.; Kwan, A.H.; Crofts, L.A.; Loughlin, F.E.; Matthews, J.M.; Crossley, M.; Mackay, J.P. Zinc fingers as protein recognition motifs: Structural basis for the GATA-1/friend of GATA interaction. Proc. Natl. Acad. Sci. USA 2005, 102, 583-588. [CrossRef] [PubMed]

76. Tronnersjo, S.; Hanefalk, C.; Balciunas, D.; Hu, G.Z.; Nordberg, N.; Muren, E.; Ronne, H. The jmjN and jmjC domains of the yeast zinc finger protein Gis1 interact with 19 proteins involved in transcription, sumoylation and DNA repair. Mol. Genet. Genomics 2007, 277, 57-70. [CrossRef] [PubMed]

77. Hon, T.; Dodd, A.; Dirmeier, R.; Gorman, N.; Sinclair, P.R.; Zhang, L.; Poyton, R.O. A mechanism of oxygen sensing in yeast. Multiple oxygen-responsive steps in the heme biosynthetic pathway affect Hap1 activity. J. Biol. Chem. 2003, 278, 50771-50780. [CrossRef] [PubMed]

78. Balciunas, D.; Ronne, H. Yeast genes GIS1-4: Multicopy suppressors of the Gal- phenotype of snf1 mig1 srb8/10/11 cells. Mol. Gen. Genet. 1999, 262, 589-599. [CrossRef] [PubMed]

79. Bandyopadhyay, S.; Mehta, M.; Kuo, D.; Sung, M.K.; Chuang, R.; Jaehnig, E.J.; Bodenmiller, B.; Licon, K.; Copeland, W.; Shales, M.; et al. Rewiring of genetic networks in response to DNA damage. Science 2010, 330, 1385-1389. [CrossRef]

80. Costanzo, M.; Baryshnikova, A.; Bellay, J.; Kim, Y.; Spear, E.D.; Sevier, C.S.; Ding, H.; Koh, J.L.; Toufighi, K.; Mostafavi, S.; et al. The genetic landscape of a cell. Science 2010, 327, 425-431. [CrossRef]

81. Costanzo, M.; VanderSluis, B.; Koch, E.N.; Baryshnikova, A.; Pons, C.; Tan, G.; Wang, W.; Usaj, M.; Hanchard, J.; Lee, S.D.; et al. A global genetic interaction network maps a wiring diagram of cellular function. Science 2016, 353, aaf1420. [CrossRef]

82. Kastaniotis, A.J.; Zitomer, R.S. Rox1 mediated repression. Oxygen dependent repression in yeast. Adv. Exp. Med. Biol. 2000, 475, 185-195.

83. Lai, L.C.; Kosorukoff, A.L.; Burke, P.V.; Kwast, K.E. Metabolic-state-dependent remodeling of the transcriptome in response to anoxia and subsequent reoxygenation in Saccharomyces cerevisiae. Eukaryot Cell 2006, 5, 1468-1489. [CrossRef] 
84. Krupp, M.; Marquardt, J.U.; Sahin, U.; Galle, P.R.; Castle, J.; Teufel, A. RNA-Seq Atlas-a reference database for gene expression profiling in normal tissue by next-generation sequencing. Bioinformatics 2012, 28, 1184-1185. [CrossRef] [PubMed]

85. Berry, W.L.; Janknecht, R. KDM4/JMJD2 histone demethylases: Epigenetic regulators in cancer cells. Cancer Res. 2013, 73, 2936-2942. [CrossRef] [PubMed]

86. Zhang, Q.J.; Chen, H.Z.; Wang, L.; Liu, D.P.; Hill, J.A.; Liu, Z.P. The histone trimethyllysine demethylase JMJD2A promotes cardiac hypertrophy in response to hypertrophic stimuli in mice. J. Clin. Invest. 2011, 121, 2447-2456. [CrossRef] [PubMed]

87. Young, L.C.; Hendzel, M.J. The oncogenic potential of Jumonji D2 (JMJD2/KDM4) histone demethylase overexpression. Biochem. Cell Biol. 2013, 91, 369-377. [CrossRef]

88. Lee, D.H.; Kim, G.W.; Jeon, Y.H.; Yoo, J.; Lee, S.W.; Kwon, S.H. Advances in histone demethylase KDM4 as cancer therapeutic targets. FASEB J. 2020, 34, 3461-3484. [CrossRef]

89. Bishop, D.F.; Anderson, K.E.; Desnick, R.J.; Sassa, S. Disorders of heme biosynthesis: X-linked sideroblastic anemia and the porphyrias. In The Online Metabolic and Molecular Bases of Inherited Disease; The McGraw-Hill Companies, Inc.: New York, NY, USA, 2016; pp. 2991-3062.

90. Hooda, J.; Shah, A.; Zhang, L. Heme, an essential nutrient from dietary proteins, critically impacts diverse physiological and pathological processes. Nutrients 2014, 6, 1080-1102. [CrossRef]

91. Mattoon, J.; Lancashire, W.; Sanders, H.; Carvajal, E.; Malamud, D.; Braz, G.; Panek, A. Oxygen and catabolite regulation of hemoprotein biosynthesis in the yeast Saccharomyces cerevisiae. In Biosynthesis of Heme and Cholorophylls; Caughey, W.J., Ed.; Academic Press: Cambridge, MA, USA, 1979; pp. 421-435.

92. Zheng, B.; Albrecht, U.; Kaasik, K.; Sage, M.; Lu, W.; Vaishnav, S.; Li, Q.; Sun, Z.S.; Eichele, G.; Bradley, A.; et al. Nonredundant roles of the mPer1 and mPer2 genes in the mammalian circadian clock. Cell 2001, 105, 683-694. [CrossRef]

93. Burch, J.S.; Marcero, J.R.; Maschek, J.A.; Cox, J.E.; Jackson, L.K.; Medlock, A.E.; Phillips, J.D.; Dailey, H.A., Jr. Glutamine via alpha-ketoglutarate dehydrogenase provides succinyl-CoA for heme synthesis during erythropoiesis. Blood 2018, 132, 987-998. [CrossRef]

94. Leurs, U.; Clausen, R.P.; Kristensen, J.L.; Lohse, B. Inhibitor scaffold for the histone lysine demethylase KDM4C (JMJD2C). Bioorg Med. Chem. Lett. 2012, 22, 5811-5813. [CrossRef]

95. Metzger, E.; Stepputtis, S.S.; Strietz, J.; Preca, B.T.; Urban, S.; Willmann, D.; Allen, A.; Zenk, F.; Iovino, N.; Bronsert, P.; et al. KDM4 Inhibition Targets Breast Cancer Stem-like Cells. Cancer Res. 2017, 77, 5900-5912. [CrossRef]

96. Tan, M.K.; Lim, H.J.; Harper, J.W. SCF(FBXO22) regulates histone H3 lysine 9 and 36 methylation levels by targeting histone demethylase KDM4A for ubiquitin-mediated proteasomal degradation. Mol. Cell Biol. 2011, 31, 3687-3699. [CrossRef] [PubMed]

97. Ipenberg, I.; Guttmann-Raviv, N.; Khoury, H.P.; Kupershmit, I.; Ayoub, N. Heat shock protein 90 (Hsp90) selectively regulates the stability of KDM4B/JMJD2B histone demethylase. J. Biol. Chem. 2013, 288, 14681-14687. [CrossRef] [PubMed]

98. Cao, C.; Vasilatos, S.N.; Bhargava, R.; Fine, J.L.; Oesterreich, S.; Davidson, N.E.; Huang, Y. Functional interaction of histone deacetylase 5 (HDAC5) and lysine-specific demethylase 1 (LSD1) promotes breast cancer progression. Oncogene 2017, 36, 133-145. [CrossRef] [PubMed]

99. Jung, I.; Seo, J.; Lee, H.S.; Stanton, L.W.; Kim, D.; Choi, J.K. Global mapping of the regulatory interactions of histone residues. FEBS Lett. 2015, 589, 4061-4070. [CrossRef] [PubMed]

(C) 2020 by the authors. Licensee MDPI, Basel, Switzerland. This article is an open access article distributed under the terms and conditions of the Creative Commons Attribution (CC BY) license (http://creativecommons.org/licenses/by/4.0/). 